\title{
Studying the Effect of Different Gas-Phase Chemical Kinetic Mechanisms on the Formation of Oxidants, Nitrogen Compounds and Ozone in Arid Regions
}

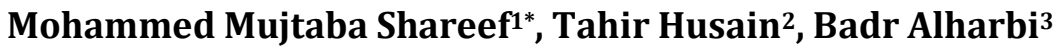 \\ ${ }^{1}$ Schulich School of Engineering, University of Calgary, Calgary, AB, Canada \\ ${ }^{2}$ Faculty of Engineering and Applied Science, Memorial Universityof Newfoundland, St. John's, NL, Canada \\ ${ }^{3}$ King Abdulaziz City for Science and Technology, Riyadh, Saudi Arabia \\ Email: *mujtaba.shareef@ucalgary.ca
}

How to cite this paper: Shareef, M.M., Husain, T. and Alharbi, B. (2019) Studying the Effect of Different Gas-Phase Chemical Kinetic Mechanisms on the Formation of Oxidants, Nitrogen Compounds and Ozone in Arid Regions. Journal of Environmental Protection, 10, 1006-1031.

https://doi.org/10.4236/jep.2019.108060

Received: June 2, 2019

Accepted: August 17, 2019

Published: August 20, 2019

Copyright $\odot 2019$ by author(s) and Scientific Research Publishing Inc. This work is licensed under the Creative Commons Attribution International License (CC BY 4.0).

http://creativecommons.org/licenses/by/4.0/

\begin{abstract}
CMAQ was implemented in the central region of Saudi Arabia and the effect of simulating models using various chemical mechanisms on selected oxidants, nitrogen species, and $\mathrm{O}_{3}$ was investigated. CB05TUCL predicted $\mathrm{OH}$, MEPX, and $\mathrm{NO}_{z}$ about 7\%, 7.7\%, and 8\% more than CB05E51 respectively; however, there was no observable difference in the $\mathrm{O}_{3}$ predictions. The differences in variations of SAPRC07 mechanism (SAPRC07TB, SAPRC07TC, and SAPRC07TIC) for all parameters were less than 1\%. RACM2 produced the highest $\mathrm{OH}$ and $\mathrm{H}_{2} \mathrm{O}_{2}$ concentrations. RACM2 enhanced $\mathrm{OH}$ production in the range of $24 \%-32 \%$ and $\mathrm{H}_{2} \mathrm{O}_{2}$ by $9 \%$ over other mechanisms; these are comparatively less than the findings of other studies. Similarly, CB05 produced over $40 \%$ more PAN concentration than CB05. Moreover, PAN concentrations produced by all mechanisms were very high compared to other studies. SAPRC07 produced approximately $3 \%$ more mean surface $\mathrm{O}_{3}$ concentration than RACM2 and approximately $10 \%$ more than CB05. RACM2 $\mathrm{O}_{3}$ predictions were higher than $\mathrm{CB} 05$ by $7 \%$. The predicted $\mathrm{O}_{3}$ concentrations by CB05, RACM2, and SAPRC07 were $6 \%, 11 \%$, and $15 \%$ more than the average observed concentrations, which indicate that closest predictions to the observed values were by CB05. This study concludes that there is a wide variation of mechanisms with respect to the predictions of oxidants and nitrogen compounds; however, less variation is noticed in predictions of $\mathrm{O}_{3}$. For any air pollution control strategies and photochemical modeling studies in the current region or in any other arid regions, the CB05 mechanism is recommended.
\end{abstract}




\section{Keywords}

Air Quality Modeling, Photochemical Mechanisms, Ozone, Riyadh, Arid, CMAQ

\section{Introduction}

Ozone $\left(\mathrm{O}_{3}\right)$ is a secondary pollutant formed because of the reactions of its precursors: nitrogen oxides $\left(\mathrm{NO}+\mathrm{NO}_{2}=\mathrm{NO}_{\mathrm{x}}\right)$ and Volatile Organic Compounds (VOCs) in the presence of sunlight. The formation of $\mathrm{O}_{3}$ in the atmosphere can be understood through a combination of measurements (of $\mathrm{O}_{3}$ and its precursors) and model predictions. Measurements are generally limited in terms of space and time, so the atmospheric chemical transport models (ACTM) fill this gap. ACTM can also estimate many chemical species that are not easily measured. Several chemical mechanisms were developed for ACTM to address the issues associated with urban and rural $\mathrm{O}_{3}$ formation. Three of the more widely used mechanisms are the Carbon Bond (CB) [1], Regional Atmospheric Chemistry Mechanism (RACM) [2], and State Air Pollution Research Center (SAPRC) [3].

The original CB mechanism, CB04, was based on the simple Arrhenius law rate constant forms that were derived from more complex temperature and pressure-dependent rate constants. It is a lumped structure type and is the fourth in a series of CB mechanisms and includes 36 species and 96 reactions of which 12 are photolytic. Subsequent changes were made by adding rate constants for the formation and decomposition of peroxyacetyl nitrates (PAN) and a termination reaction between the $\mathrm{XO}_{2}$ and $\mathrm{XO}_{2} \mathrm{~N}$ operator and the $\mathrm{HO}_{2}$ radical. Carter and Atkinson in 1996 enhanced the mechanism by updating the isoprene chemistry [4]. Yarwood et al. in 2005 proposed a major kinetic and photolysis update to CB04 and extended the inorganic reaction set [5].

The new CB05 mechanism was shown to enhance the model performance for $\mathrm{O}_{3}$ and organic carbons in rural areas and high altitude conditions [6]. CB05 was further improved to include toluene chemistry (CB05TU), and it was proved that $\mathrm{CB} 05 \mathrm{TU}$ enhances the prediction of $\mathrm{O}_{3}$ formation rate [7]. The CB mechanism has been widely used in several studies, to develop reduced form models [8] [9] [10] and to study $\mathrm{O}_{3}$ and meteorological sensitivities [11] [12] [13]. Dunker et al. in 2002 used CB05 to study the oxidation of reactive VOCs and other processes [14]. Community Multiscale Air Quality (CMAQ) implements two enhanced versions of the CB05 mechanisms, namely cb05e51 and cb05tucl. The enhancements include the updates in molecular hydrolysis and rate constants based on the recent International Union of Pure and Applied Chemistry [15]. Cb05e51 consists of 148 species and 343 reactions, and cb05tucl includes 107 species and 238 reactions, as shown in Table 1 and Table 2.

The regional acid deposition model (RADM2) is a lumped species mechanism that uses a reactivity-based weighting scheme to account for lumping chemical 
Table 1. Summary of chemical mechanisms and their variations.

\begin{tabular}{cc}
\hline Chemical Mechanism & Variation \\
\hline CB05 & CB05E51 \\
RACM & CB05TUCL \\
& RACM2 \\
SAPRC07 & SAPRC07TB \\
& SAPRC07TC \\
& SAPRC07TIC \\
\hline
\end{tabular}

Table 2. Number of species and reactions in different chemical mechanisms.

\begin{tabular}{cccc}
\hline Sno. & Chemical Mechanism & Species & Reactions \\
\hline 1 & CB05E51 & $148($ Aerosol $=25 ;$ Gas $=123)$ & 343 \\
2 & CB05TUCL & $107($ Aerosol $=24 ;$ Gas $=83)$ & 235 \\
3 & SAPRC07TC & $186($ Aerosol $=25 ;$ Gas $=161)$ & 741 \\
4 & SAPRC07TB & $186($ Aerosol $=25 ;$ Gas $=161)$ & 457 \\
5 & SAPRC07TIC & $231($ Aerosol $=33 ;$ Gas $=198)$ & 928 \\
6 & RACM2 & $156($ Aerosol $=22 ;$ Gas $=134)$ & 400 \\
\hline
\end{tabular}

compounds into surrogate species. It was built on the RADM1 [2] by including higher classes of alkenes and isoprene, more detailed aromatic chemistry, and the treatment of peroxy radical reactions [16]. The photo-oxidation of isoprene was further improved in RADM2 by Zimmermann and Poppe in 1996 [17]. The base mechanism includes 57 model species and 158 reactions, 21 of which are photolytic. RADM2 was later updated to the Regional Atmospheric Chemistry Mechanism RACM [16] and recently to RACM2 [18]. The updated version, RACM2, implemented in CMAQ consists of about 400 chemical reactions and 156 chemical species, as shown in Table 2. The kinetic data used in the reactions include the recent suggestions of IUPAC [15] and NASA/JPL [19]. This mechanism was used to study heterogeneous chemistry [20] and sensitivity analysis with respect to the microphysics scheme in WRF-Chem [21].

The original version of SAPRC99 is a detailed mechanism for gas-phase atmospheric reactions of VOCs and $\mathrm{NO}_{\mathrm{x}}$ in urban and regional atmospheres, the details of which are documented by Carter in 2000 [3]. SAPRC99 was later updated to SAPRC07 to reflect the new kinetic and mechanistic data and to incorporate new data on several types of VOCs. The versions available in CMAQ are saprc07tb and saprc07tc; both consist of 186 species and 741 chemical reactions. In another SAPRC version in CMAQ, saprc07tic, the number of species has been increased to 231, as shown in Table 1.

The three chemical mechanisms discussed above share the common concept of reaction rates and products; however, they differ in terms of rate constants, photolysis (due to change in pressure and temperature), and treatment of or- 
ganic and inorganic chemistry. Several studies have compared these mechanisms and found large variations between model predictions.

Jimenez et al. in 2003 reported considerable variation in model predictions when using CB04 and SAPRC99, particularly in the reactive species $\mathrm{HO}_{2}$ and $\mathrm{NO}_{3}$ [22]. A comparison between RADM2 and its updated version RACM2 under urban and rural conditions showed large species and process differences in organic speciation [23]. Tonnesen and Luecken in 2004 [24] studied the differences between two mechanisms: CB04 and SAPRC99 and observed that differences in production and propagation of $\mathrm{HOX}\left(\mathrm{HO}_{2}\right.$ and hydroxyl radicals $)$ and organic peroxy radicals affect $\mathrm{O}_{3}$ formation. Both Byun et al. in 2006 [25] and Faraji et al. in 2008 [26], while using air quality models with versions of CB04 and SAPRC99 over southeast Texas, predicted more $\mathrm{O}_{3}$ with SAPRC99. Luecken et al. in 2008 [27] also reported higher concentrations of $\mathrm{O}_{3}$ using SAPRC99. The predicted $\mathrm{O}_{3}$ concentrations are similar for most of the USA, but statistically significant differences occur over many urban areas and the central USA. They also noted that the difference in $\mathrm{O}_{3}$ predictions depends on the location, the VOC/NO $\mathrm{Na}_{\mathrm{x}}$ ratio, and concentrations of precursor pollutants. Sarwar et al. in 2013 [28] compared atmospheric compositions using CB05TU and RACM2 and reported large variations in the predictions of various chemical species. The two mechanisms CB05 and RACM2 were compared in a domain in India, and it was observed that $\mathrm{O}_{3}$ concentrations are better predicted by the CB05 mechanism [13].

The problem of $\mathrm{O}_{3}$ is generally of concern in large cities due to its role in the formation of photochemical smog, and the city of Riyadh in Saudi Arabia is no exception. Recent studies show the declining trend of air quality [29] [30] [31], and Riyadh is reported to be one of the top 10 cities in the world with urban smog problems. In Riyadh, ACTM can be implemented to evaluate various air pollution strategies to control $\mathrm{O}_{3}$ and its precursors and to improve air quality in Riyadh and its vicinity. Applying the correct chemical mechanism in ACTM is fundamental in formulating the appropriate mitigation measures.

Atmospheric chemical mechanisms have not been studied in arid regions such as Saudi Arabia before. Therefore, the aim of this paper is to identify the impacts of using various chemical mechanisms on the formation of $\mathrm{O}_{3}$, selected oxidants $\left(\mathrm{OH}\right.$ and $\mathrm{H}_{2} \mathrm{O}_{2}$ ), and nitrogen species ( $\mathrm{PAN}$ and $\mathrm{NO}_{\mathrm{z}}$ ) in the central region of Saudi Arabia. This will provide insight into the formation of $\mathrm{O}_{3}$ and assist regulatory agencies in designing effective $\mathrm{O}_{3}$ control strategies. Moreover, it will also serve as a benchmark for any future implementations of ACTM in this region as well as similar regions.

\section{Methodology}

All simulations were performed using CMAQ which is a 3D grid-based air quality model developed by the United States Environmental Protection Agency (US EPA). It simulates $\mathrm{O}_{3}$, photochemical oxidants, particulate matter (PM), and 
deposition of pollutants such as acids, toxic pollutants, and nitrogen species. $\mathrm{CMAQ}$ is an active open-source project that continuously enhances the accuracy and efficiency of photochemical modeling by taking advantage of state-of-the-art multi-processor computing techniques. It is maintained by the Community Modeling \& Analysis System (CMAS), the details of which can be found at their website [32]. Several recent studies have used CMAQ to study atmospheric chemistry [6] [28] [33], uncertainty [10] [34], haze pollution [35], biomass burning [36], and health impact [37]; however, to the knowledge of authors no published study has implemented CMAQ in Saudi Arabia.

The meteorological fields for the study were generated by the Weather Research and Forecasting (WRF) version 3.4.1; it is a next-generation mesoscale model that uses an updated four-dimensional data assimilation approach [38]. The physics options selected for the WRF simulations are summarized in Table 3. The WRF meteorological data was applied to a Meteorology Chemistry Interface Processor (MCIP) to develop the meteorological input dataset required for the CMAQ simulations. The horizontal domain in both the WRF and CMAQ covers the central region of Saudi Arabia centering approximately at Riyadh with a resolution of $4 \mathrm{~km}$ and $312 \mathrm{~km} \times 312 \mathrm{~km}$ extent (Figure 1). CMAQ version 5.1 was used to run the simulations. The configurations and options used in the model are summarized in Table 4. One month simulations were performed for July 2012 with six different chemical mechanisms. This time period was chosen to compare the model results with $\mathrm{O}_{3}$ data collected at various locations.

The chemical mechanisms included variations of cb05 (CB05E51 and CB05TUCL), racm ( $\mathrm{racm} 2$ ), and saprc07 (saprc07tb, saprc07tc, and saprc07tic) totalling six simulations as summarized in Table 1. The Rosenbrock third order numerical solver [39] was used to solve the system of differential equations for gas-phase chemistry. Clean air was assumed as the initial and boundary conditions. In most studies, spin-up periods are used to minimize the effect of initial conditions in the model, so 50 hours of simulation time was used as a spin-up period

Table 3. WRF domain configurations and major physics options.

\begin{tabular}{ll}
\hline Simulation Period & July 2012 \\
Domain & $312 \mathrm{~km} \times 312 \mathrm{~km}$ \\
Horizontal Resolution & $4 \mathrm{~km}$ \\
Vertical Resolution & $1 \mathrm{~km}$ \\
Initial and Boundary Conditions & (NCEP) National Centre for Environmental Prediction [51] \\
Shortwave Radiation & Rapid Radiative Transfer Model (RRTM) [52] \\
Longwave Radiation & Rapid Radiative Transfer Model (RRTM) [52] \\
Land Use & Noah Land Surface Model [53] \\
Surface Layer & Monin-Obukhov similarity theory \\
Planetary Boundary Layer Model & Mellor-Yamada-Janjic scheme [54] \\
Cloud Microphysics & Kain-Fritsch scheme [55]
\end{tabular}




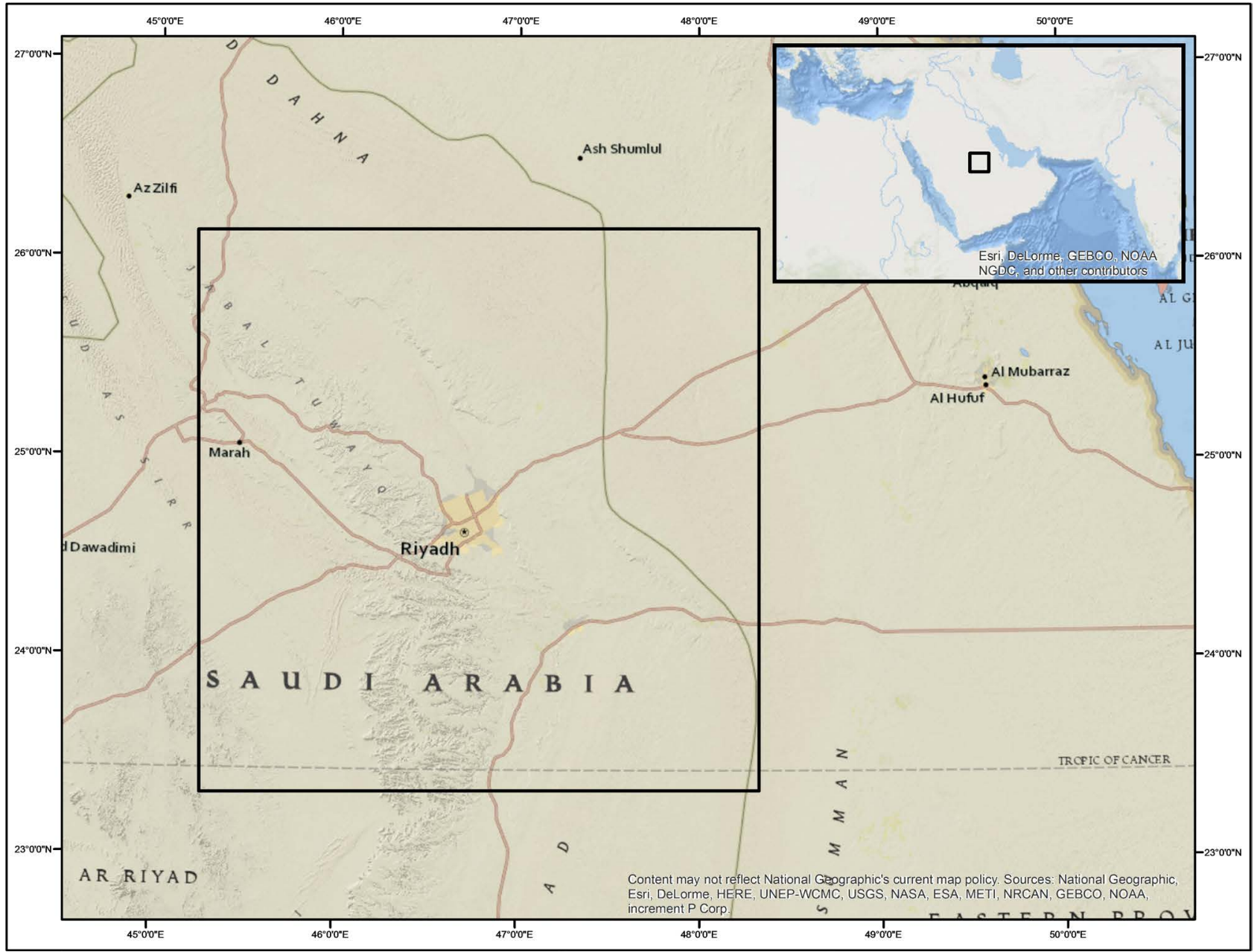

Figure 1. WRF and CMAQ modeling domain.

Table 4. CMAQ configuration and options.

Simulation Period
Domain
Horizontal Resolution
Vertical Resolution
Initial and Boundary Conditions
Aerosol Module

July 2012

$312 \mathrm{~km} \times 312 \mathrm{~km}(78 \times 78)$

$4 \mathrm{~km}$

$1 \mathrm{~km}$

Clean air

Sixth-generation modal CMAQ aerosol model with extensions for sea salt emissions and thermodynamics; includes a new formulation for secondary organic aerosol yields (aero6)

Photolytic Rate

Clear-sky photolysis rates off-line using the CMAQ program JPROC; provide daily photolysis rate look-up tables to CCTM

Chemistry Solver

Rosenbrock chemistry solver (ros3)

Cloud Module

Cloud processor that uses ACTM methodology to compute convective mixing with heterogeneous chemistry for AERO6 (cloud_acm_ae6)

Windblown Dust

None

Lighting NOx

No lightning, no emissions 
in this study, as recommended by Harley et al. in 2006 [40].

Biogenic emissions were calculated based on Model of Emissions of Gases and Aerosols from Nature (MEGAN), and anthropogenic emissions were estimated by a combination of direct sources of inventories and indirect calculations from the source data. MEGAN v2.1 [41] [42] was configured to generate these emissions biogenic emissions. MEGAN is a modeling system for estimating terrestrial emissions of gases and aerosols. To generate the atmospheric emissions, MEGAN requires information related to land-cover, weather, and atmospheric chemical composition. Land-cover variables include emission factors, leaf area index, and plant functional types; this data was downloaded from MEGAN's global distributions and processed for the area using the ESRI ArcGIS tools [43]. The appropriate mapping of emissions of real organic species to the emissions of mechanism species is vital for the effective use of condensed mechanisms in air quality models. Carter, W. P. L in 2015 [44] documented the mapping for different mechanisms; however, in MEGAN v2.1, the assignments for the mechanisms are built into the code. Subsequently, MEGAN tools were run and the emission files were merged using Sparse Matrix Operator Kernel Emissions (SMOKE v3.65) system [32] to generate hourly gridded and speciated model-ready emissions files. Two main sources were considered for anthropogenic emissions, the mobile source such as emissions from automobiles and static sources such as emissions from power plants and factories.

This paper presents the results of the comparison between various chemical mechanisms on the formation of the selected HOX, nitrogen compounds, and $\mathrm{O}_{3}$. The surface $\mathrm{O}_{3}$ concentrations were also compared with the observed data.

\section{Results and Discussion}

\subsection{Comparing Variations of CB05 and SAPRC07}

\subsubsection{CB05E51 and CB05TUCL}

Table 5 presents the domain-wide mean concentrations of various species simulated with six different chemical mechanisms including the variations of $\mathrm{CB}$ (CB05E51 and CB05TUCL). The differences in the mean concentrations between the two $\mathrm{CB}$ mechanisms were less than $1 \%$ except for $\mathrm{OH}, \mathrm{NO}_{z}$, and MEPEX which had differences of 7\%, 7.7\% and $8 \%$ more than CB05TUCL respectively. The differences in the mean concentration of $\mathrm{O}_{3}$ (shown in Figure 2) were less than $0.5 \%$; this implies that there is no significant difference between the mechanisms when producing $\mathrm{O}_{3}$. In order to compare with the other mechanisms, the concentrations for the various parameters for CB05E51 and CB05TUCL were averaged and referred to as CB05.

\subsubsection{SAPRC07TB, SAPRC07TC and SAPRC07TIC}

The three variations of SAPRC07 (saprc07tb, saprc07tc and saprc07tic) produced similar concentrations for various species. The differences between the species as presented in Table 5 are less than $1 \%$ implying that no significant differences exist in terms of producing the listed species. The concentrations 
Table 5. Domain-wide mean concentrations predicted by six chemical mechanisms during the modeling period.

\begin{tabular}{cccccccc}
\hline Species & Unit & CB05E51 & CB05TUCL & SAPRC07TB & SAPRC07TC & SAPRC07TIC & RACM2 \\
\hline Hydroxyl Radical $(\mathrm{OH})$ & pptv & 0.16 & 0.14 & 0.15 & 0.15 & 0.15 & 0.18 \\
Hydrogen Peroxide $\left(\mathrm{H}_{2} \mathrm{O}_{2}\right)$ & pptv & 1535.6 & 1540.0 & 1527.9 & 1527.9 & 1538.9 & 1599.4 \\
Methylhydroperoxide (MEPX) & pptv & 258.2 & 236.9 & 204.3 & 204.3 & 204.3 & 7.0 \\
Nitric Acid $\left(\mathrm{HNO}_{3}\right)$ & pptv & 393.8 & 369.8 & 368.8 & 368.8 & 374.2 & 402.8 \\
Peroxyacetyl Nitrate (PAN) & pptv & 9.3 & 9.1 & 5.9 & 5.9 & 5.8 & 3.3 \\
Nitrogen Oxide $(\mathrm{NO})$ & pptv & 2660.8 & 2658.2 & 2668.7 & 2668.7 & 2664.1 & 2702.9 \\
Nitrogen Dioxide $\left(\mathrm{NO}_{2}\right)$ & pptv & 3198.1 & 3226.8 & 3217.8 & 3217.6 & 3218.0 & 3155.5 \\
Secondary Nitrogen $\left(\mathrm{NO}_{2}\right)$ & pptv & 518.9 & 511.7 & 6357.7 & 6357.7 & 6361.5 & 533.4 \\
Ozone $\left(\mathrm{O}_{3}\right)$ & ppbv & 41.6 & 42.1 & 45.5 & 45.3 & 45.4 & 43.5 \\
\hline
\end{tabular}

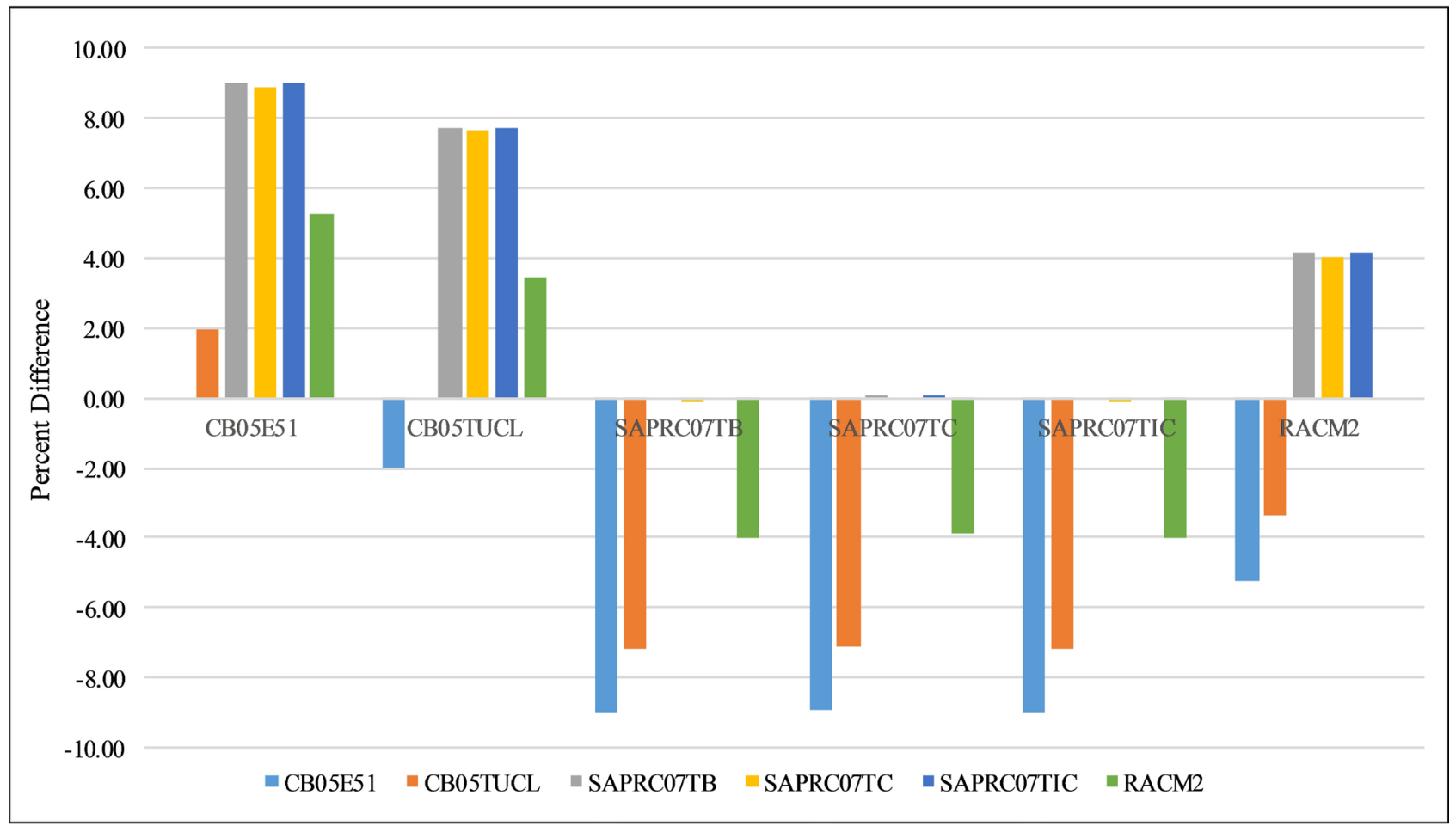

Figure 2. Comparison of mean $\mathrm{O}_{3}$ concentration for various chemical mechanisms.

produced by the three variations were averaged and were called SAPRC07 to compare with the other mechanisms.

\subsection{Comparing CB05, SAPRC07 and RACM2}

\subsubsection{Selected 0xidants}

\section{1) Effect on Hydroxyl Radical (OH)}

The atmospheric oxidation capacity is determined by the presence of an $\mathrm{OH}$ radical, as it reacts with many trace species in the atmosphere. Domain-wide mean $\mathrm{OH}$ concentrations predicted by CB05, SAPRC07, and RACM2 were 0.15 pptv, 0.15 pptv, and 0.18 pptv respectively. While there was no significant dif- 
ference between the $\mathrm{CB} 05$ and SAPRC07 predictions, RACM2 predicted about $25 \%$ more $\mathrm{OH}$ than $\mathrm{CB} 05$ and SAPRC07 (Table 6). Spatial variation of the $\mathrm{OH}$ radical and the pertaining percent differences are shown in Figure 3. CB05 and SAPRC07 predicted the highest amount in the north $(0.160 \mathrm{pptv})$, and both were close to zero in south. On the other hand, RACM2 predicted a high of $54 \mathrm{pptv}$ in the southwest and a low of $6 \mathrm{pptv}$ in and around the centre. Compared to CB05, RACM2 enhanced OH mostly in the range of $24 \%-32 \%$ and the maximum enhancement was $64 \%$, and SAPRC07 enhanced in the range of $24 \%-30 \%$ with a maximum enhancement reaching $60 \%$. The overall maximum enhancement was observed in the southwest of the domain. This is the same area where $\mathrm{O}_{3}$ is produced in high concentrations (described later). Some of the reasons that can be attributed to this high $\mathrm{OH}$ production by RACM2 are explained ahead.

Firstly, RACM2 produces more $\mathrm{O}_{3}$ and subsequently generates more $\mathrm{O}$ atoms under photolysis, and $\mathrm{O}$ atoms react with $\mathrm{H}_{2} \mathrm{O}$ to produce $\mathrm{OH}$ radicals. Secondly, the lower reaction rate of $\mathrm{NO}_{2}+\mathrm{OH}$ in $\mathrm{RACM} 2$, consumes less $\mathrm{OH}$ radicals from the atmosphere compared to CB05 and SAPRC07. Sarwar et al. in 2013 [28] states that additional reactions in RACM2 with olefins and methacrolein may be another reason for higher $\mathrm{OH}$ production. However, this does not seem to be the case, as the reactions with acrolein exist in all the three mechanisms at similar rates. The CMAQ model species name for methacrolein in $\mathrm{CB} 05$ is MAPAN and the species name in SAPRC07 and RACM2 is MACR.

In the study's US domain, Sarwar et al. in 2013 [28] observed that $\mathrm{OH}$ enhancement by RACM2 was in the range of $36 \%-60 \%$. Comparing these results, the enhancements in this study were mostly in the range of $24 \%-32 \%$, which is significantly lower than the US domain. This could be due to the shortage of $\mathrm{H}_{2} \mathrm{O}$ in Saudi Arabia as it is dry and arid. $\mathrm{OH}$ measurements were not performed in the study area; hence, the model predictions could not be compared with field

Table 6. Domain-wide mean concentrations during the modeling period of various species averaged by variations (CB05, SAPRC07, and RACM2).

\begin{tabular}{|c|c|c|c|c|c|c|c|}
\hline \multirow[b]{2}{*}{ Species } & \multirow[b]{2}{*}{ Unit } & \multirow[b]{2}{*}{ СB05 } & \multirow[b]{2}{*}{ SAPRC07 } & \multirow[b]{2}{*}{ RACM2 } & \multicolumn{3}{|c|}{ Percent Differences } \\
\hline & & & & & $\begin{array}{c}\text { CB05 vs } \\
\text { SAPRC07 }^{1}\end{array}$ & $\begin{array}{l}\text { CB05 vs } \\
\text { RACM2 }^{2}\end{array}$ & 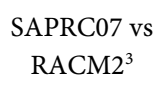 \\
\hline Hydroxyl Radical (OH) & pptv & 0.15 & 0.15 & 0.18 & -2.06 & 25.26 & 25.26 \\
\hline Hydrogen Peroxide $\left(\mathrm{H}_{2} \mathrm{O}_{2}\right)$ & pptv & 1537.80 & 1531.57 & 1599.40 & -0.41 & 4.43 & 4.43 \\
\hline Methylhydroperoxide (MEPX) & pptv & 247.59 & 204.32 & 7.03 & -17.48 & -96.56 & -96.56 \\
\hline Nitric Acid $\left(\mathrm{HNO}_{3}\right)$ & pptv & 381.81 & 370.65 & 402.87 & -2.92 & 8.69 & 8.69 \\
\hline Peroxyacetyl Nitrate (PAN) & pptv & 9.18 & 5.88 & 3.28 & -35.98 & -44.14 & -44.14 \\
\hline Nitrogen Oxide (NO) & pptv & 2659.51 & 2667.21 & 2702.91 & 0.29 & 1.34 & 1.34 \\
\hline Nitrogen Dioxide $\left(\mathrm{NO}_{2}\right)$ & pptv & 3212.46 & 3217.73 & 3155.54 & 0.16 & -1.93 & -1.93 \\
\hline Secondary Nitrogen $\left(\mathrm{NO}_{z}\right)$ & pptv & 515.31 & 6358.97 & 533.38 & 1134.00 & -91.61 & -91.61 \\
\hline Ozone $\left(\mathrm{O}_{3}\right)$ & ppbv & 41.67 & 45.33 & 43.54 & 8.78 & 4.47 & -3.96 \\
\hline
\end{tabular}

${ }^{1} 100 \times(\mathrm{SAPRC} 07-\mathrm{CB} 05) / \mathrm{CB} 05 ;{ }^{2} 100 \times(\mathrm{RACM} 2-\mathrm{CB} 05) / \mathrm{CB} 05 ;{ }^{3} 100 \times(\mathrm{RACM} 2-\mathrm{SAPRC} 07) / \mathrm{SAPRC} 07$. 

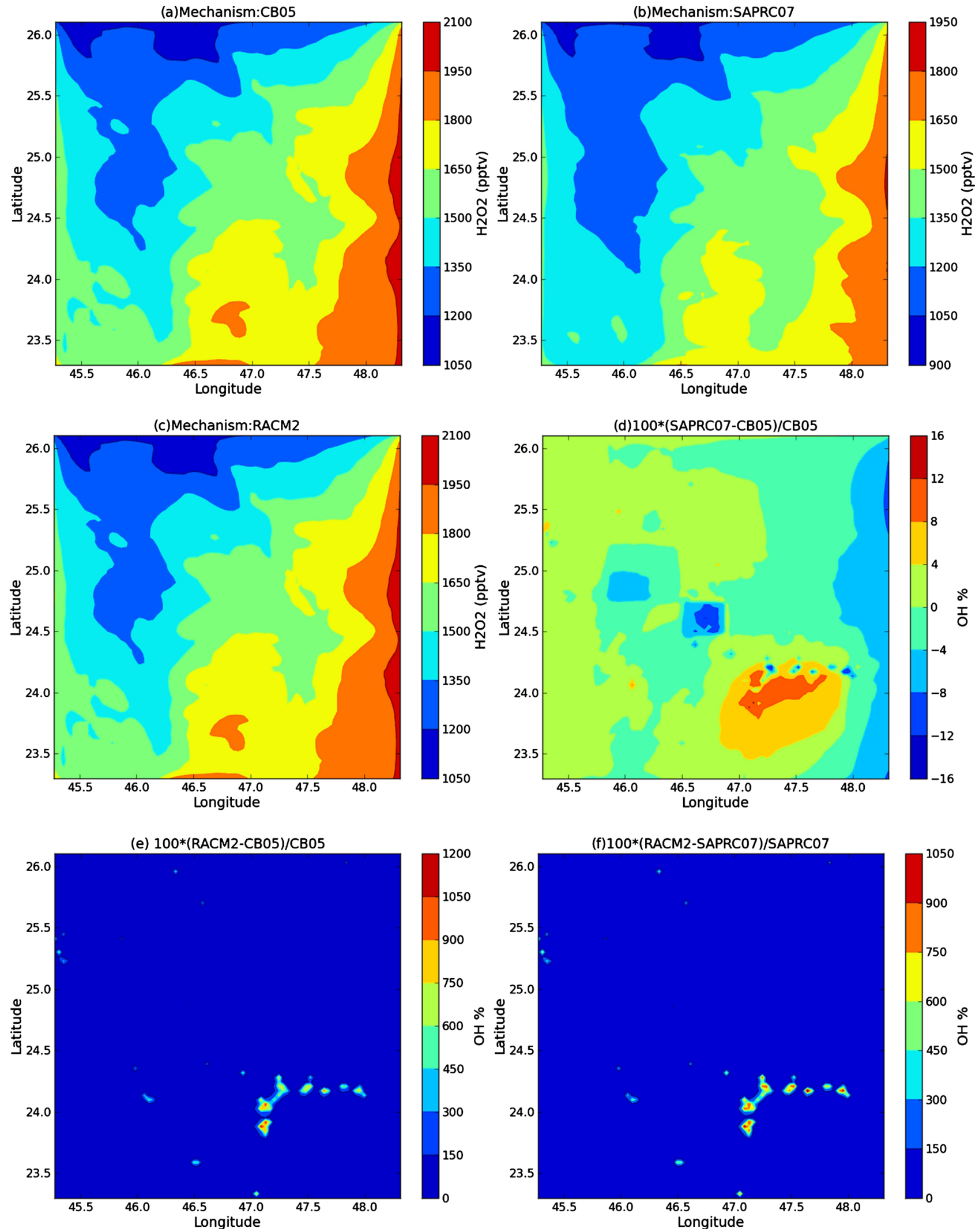

Figure 3. Spatial distribution of predicted mean $\mathrm{OH}$ concentrations obtained with chemical mechanism (a) CB05 (b) SAPRC07 (c) RACM2 and percent differences between the mechanisms (d) SAPRC07 and CB05 (e) RACM2 and CB05 (f) RACM2 and SAPRC07. 
measurements. Some studies suggested that RACM2 under-predicts the observed $\mathrm{OH}$ by $15 \%$ and $\mathrm{CB} 05$ by $30 \%$ with respect to field measurements [29] [45] (Mao et al., 2010; Lu et al., 2013).

\section{2) Effect on Hydrogen Peroxide $\left(\mathrm{H}_{2} \mathrm{O}_{2}\right)$}

$\mathrm{H}_{2} \mathrm{O}_{2}$ exists in substantial amounts in both gaseous and aqueous phases inside clouds, and it is considered the most efficient oxidant in the aqueous phase and is known to convert $\mathrm{SO}_{2}$ to $\mathrm{SO}_{4}$ [46] (Seinfield and Pandis, 2016). Spatial variation of the $\mathrm{H}_{2} \mathrm{O}_{2}$ radical and the pertaining percent differences are shown in Figure 4. SAPRC07 and CB05 predicted similar $\mathrm{H}_{2} \mathrm{O}_{2}$ concentrations in the domain, varying from $1.05 \mathrm{ppbv}$ in the north to $2.1 \mathrm{ppbv}$ towards the southeast. RACM2 produced up to $9 \%$ more $\mathrm{H}_{2} \mathrm{O}_{2}$ than the other two, with its highest concentration in the south. The chemical reactions and rates governing the formation and destruction of $\mathrm{H}_{2} \mathrm{O}_{2}$ under various chemical mechanisms are shown in Table 7. The formation of $\mathrm{H}_{2} \mathrm{O}_{2}$ in CB05 and SAPRC07 is similar except for the additional reaction $\mathrm{OH}+\mathrm{OH}=\mathrm{H}_{2} \mathrm{O}_{2}$ in $\mathrm{CB} 05$, however, it also has an additional destruction reaction $\left(\mathrm{H}_{2} \mathrm{O}_{2}+\mathrm{O}=\mathrm{OH}+\mathrm{HO}_{2}\right)$. RACM2 produces additional $\mathrm{H}_{2} \mathrm{O}_{2}$ because of the reactions of $\mathrm{O}_{3}$ with different organic compounds (such as alkenes), as shown in Table 6. RACM2 has the highest $\mathrm{H}_{2} \mathrm{O}_{2}$ formation potentially due to these reactions unlike other findings [28]. This implies that organic compounds have a significant role in the formation and destruction of $\mathrm{O}_{3}$.

\subsubsection{Selected Nitrogen Species}

\section{1) Effect on Peroxyacyl Nitrates (PAN)}

PAN is one of the components of photochemical smog and forms with the reaction of aldehydes and $\mathrm{NO}_{2}$ as shown in Table 8. Although the reaction rates differ (RACM2 reaction rate being the highest), the formation mechanisms of the three mechanisms are similar. The reverses of the same mechanisms destroy PAN; additionally, it is also destroyed with the formation of $\mathrm{NO}_{2}, \mathrm{NO}_{3}$ and other compounds. In RACM2, PAN reacts with $\mathrm{OH}$ to form $\mathrm{NO}_{3}$ and other organic compounds. Figure 5 shows the spatial distribution of the mean PAN concentration and percent differences predicted by the three mechanisms. In most of the domain, all three mechanisms produced concentrations in the range $0-8$ ppbv, but there were few patches of concentrations in the north ranging from 48 to 64 ppbv. CB05 produced the maximum concentration followed by RACM2 and SAPRC07. Due to large differences in the concentrations at certain locations, the percent differences showed a wide variation. The concentrations of PAN predicted by all mechanisms, when compared with another study [28], are high. This indicates that there is high formation of photochemical smog in certain areas in the domain. The reason for this high concentration and its formation requires further analysis.

\section{2) Effect on Secondary nitrogen species $\left(\mathrm{NO}_{z}\right)$}

$\mathrm{NO}_{z}$ was calculated based on equations presented in Table 9 for the three mechanisms. Figure 6 shows the variation of the mean concentration of $\mathrm{NO}_{z}$ 

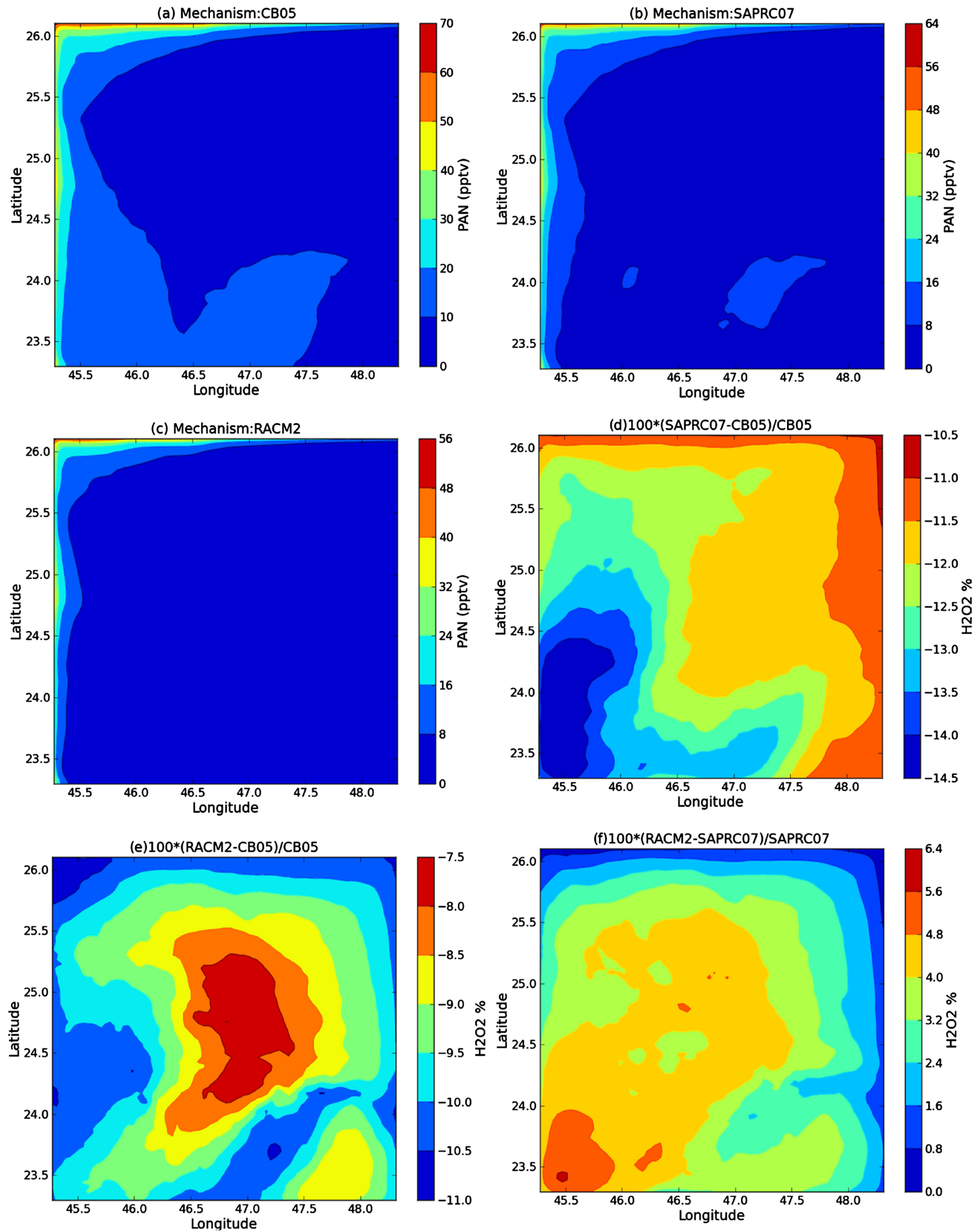

Figure 4. Spatial distribution of predicted mean $\mathrm{H}_{2} \mathrm{O}_{2}$ concentrations obtained with chemical mechanisms (a) CB05 (b) SAPRC07 (c) RACM2 and percent differences between the mechanisms (d) SAPRC07 and CB05 (e) RACM2 and CB05 (f) RACM2 and SAPRC07. 
Table 7. Chemical reactions and rates describing the formation and destruction of $\mathrm{H}_{2} \mathrm{O}_{2}$ in various mechanisms.

\begin{tabular}{|c|c|c|c|}
\hline \multirow{2}{*}{ Reactions } & \multicolumn{3}{|c|}{ Reaction Rates } \\
\hline & RACM2 & CB05 & SAPRC07 \\
\hline \multicolumn{4}{|l|}{ Formation } \\
\hline $\mathrm{HO}_{2}+\mathrm{HO}_{2}=\mathrm{H}_{2} \mathrm{O}_{2}$ & $\mathrm{k}_{1}=2.2 \mathrm{E}-13 \exp ^{(600 . / \mathrm{T})}$ & $\mathrm{k}_{1}=2.3 \mathrm{E}-13^{\star} \exp ^{(600 / \mathrm{T})}$ & $\mathrm{k}_{1}=2.20 \mathrm{e}-13^{\star} \exp ^{(600 / \mathrm{T}}$ \\
\hline $\mathrm{HO}_{2}+\mathrm{HO}_{2}+\mathrm{H}_{2} \mathrm{O}=\mathrm{H}_{2} \mathrm{O}_{2}$ & $\mathrm{k}_{1}=3.08 \mathrm{E}-34^{(2800 . / \mathrm{T})}$ & $\mathrm{k}_{1}=3.22 \mathrm{E}-34^{*} \exp ^{(2800 / \mathrm{T})}$ & $\mathrm{k}_{1}=3.08 \mathrm{e}-34^{*} \exp ^{(2800 / \mathrm{T})}$ \\
\hline $\mathrm{OH}+\mathrm{OH}=\mathrm{H}_{2} \mathrm{O}_{2}$ & - & $\mathrm{k}_{0}=6.9 \mathrm{E}-31^{\star}(\mathrm{T} / 300)^{(-1.0)}$ & - \\
\hline $\mathrm{OLT}+\mathrm{O}_{3}=\mathrm{H}_{2} \mathrm{O}_{2}+$ other compounds & $4.33 \mathrm{E}-15^{\star} \exp ^{(-1800.0 / \mathrm{T})}$ & - & - \\
\hline DIEN $+\mathrm{O}_{3}=\mathrm{H}_{2} \mathrm{O}_{2}+$ other compounds & $1.34 \mathrm{E}-14^{*} \exp ^{(-2283.0 / \mathrm{T})}$ & - & - \\
\hline ISO $+\mathrm{O}_{3}=\mathrm{H}_{2} \mathrm{O}_{2}+$ other compounds & $7.86 \mathrm{E}-15^{*} \exp ^{(-1913 . / \mathrm{T})}$ & - & - \\
\hline API $+\mathrm{O}_{3}=\mathrm{H}_{2} \mathrm{O}_{2}+$ other compounds & $5.0 \mathrm{E}-16^{*} \exp ^{(-530 . / \mathrm{T})}$ & - & - \\
\hline $\mathrm{LIM}+\mathrm{O}_{3}=\mathrm{H}_{2} \mathrm{O}_{2}+$ other compounds & $2.95 \mathrm{E}-15^{\star} \exp ^{(-783 . / \mathrm{T})}$ & - & - \\
\hline \multicolumn{4}{|l|}{ Destruction } \\
\hline $\mathrm{H}_{2} \mathrm{O}_{2}=2 \mathrm{OH}$ & $1.0 /<\mathrm{H}_{2} \mathrm{O}_{2 \_} \mathrm{RACM} 2>$ & $1.0 /<\mathrm{H}_{2} \mathrm{O}_{2} \_$IUPAC10 $>$ & $1.0 /<\mathrm{H}_{2} \mathrm{O}_{2}>$ \\
\hline $\mathrm{H}_{2} \mathrm{O}_{2}+\mathrm{O}=\mathrm{OH}+\mathrm{HO}_{2}$ & & $1.4 \mathrm{E}-12^{\star} \exp ^{(-2000 . / \mathrm{T})}$ & \\
\hline $\mathrm{H}_{2} \mathrm{O}_{2}+\mathrm{OH}=\mathrm{HO}_{2}$ & $2.9 \mathrm{E}-12^{\star} \exp ^{(-160 . / \mathrm{T})}$ & & $1.80 \mathrm{e}-12$ \\
\hline OLT $+\mathrm{O}_{2}=\mathrm{H}_{2} \mathrm{O}_{2}+$ other compounds & $4.33 \mathrm{E}-15^{\star} \exp ^{(-1800.0 / \mathrm{T})}$ & - & - \\
\hline DIEN $+\mathrm{O}_{2}=\mathrm{H}_{2} \mathrm{O}_{2}+$ other compounds & $1.34 \mathrm{E}-14^{\star} \exp ^{(-2283.0 / \mathrm{T})}$ & - & - \\
\hline ISO $+\mathrm{O}_{2}=\mathrm{H}_{2} \mathrm{O}_{2}+$ other compounds & $7.86 \mathrm{E}-15^{\star} \exp ^{(-1913 . / \mathrm{T})}$ & - & - \\
\hline API $+\mathrm{O}_{2}=\mathrm{H}_{2} \mathrm{O}_{2}+$ other compounds & $5.0 \mathrm{E}-16^{*} \exp ^{(-530 . / \mathrm{T})}$ & - & - \\
\hline $\mathrm{LIM}+\mathrm{O}_{2}=\mathrm{H}_{2} \mathrm{O}_{2}+$ other compounds & $2.95 \mathrm{E}-15^{*} \exp ^{(-783 . / \mathrm{T})}$ & - & - \\
\hline
\end{tabular}

Table 8. Chemical reactions and rates describing the formation and destruction of PAN in various mechanisms.

\begin{tabular}{|c|c|c|c|}
\hline \multirow{2}{*}{ Reactions } & \multicolumn{3}{|c|}{ Reaction Rates } \\
\hline & RACM2 & CB05 & SAPRC07 \\
\hline \multicolumn{4}{|l|}{ Formation } \\
\hline $\mathrm{C}_{2} \mathrm{O}_{3}+\mathrm{NO}_{2}=\mathrm{PAN}$ & - & $\mathrm{k}_{0}=4.9 \mathrm{E}-3^{\star} \exp ^{(-12,100 / \mathrm{T})}$ & - \\
\hline $\mathrm{MECO}_{3}+\mathrm{NO}_{2}=\mathrm{PAN}$ & - & & $\mathrm{k}_{0}=2.70 \mathrm{e}-28^{\star}(\mathrm{T} / 300)^{(-7.10)}$ \\
\hline $\mathrm{ACO}_{3}+\mathrm{NO}_{2}=\mathrm{PAN}$ & $\mathrm{k}_{0}=9.7 \mathrm{E}-29^{\star}(\mathrm{T} / 300)^{(-5.6)}$ & & \\
\hline \multicolumn{4}{|l|}{ Destruction } \\
\hline $\mathrm{PAN}=\mathrm{C}_{2} \mathrm{O}_{3}+\mathrm{NO}_{2}$ & - & $\mathrm{k}_{0}=4.9 \mathrm{E}-3^{*} \exp ^{(-12,100 / \mathrm{T})}$ & \\
\hline $\mathrm{PAN}=\mathrm{MECO}_{3}+\mathrm{NO}_{2}$ & - & - & $\mathrm{k}_{0}=4.90 \mathrm{e}-03^{*} \exp ^{(-12,100 / \mathrm{T})}$ \\
\hline $\mathrm{PAN}=\mathrm{ACO}_{3}+\mathrm{NO}_{2}$ & $9.00 \mathrm{E}-29^{\star} \exp ^{(14,000 / \mathrm{T})}$ & - & - \\
\hline $\mathrm{PAN}=0.6^{*} \mathrm{NO}_{2}+0.6 * \mathrm{C}_{2} \mathrm{O}_{3}+0.4 * \mathrm{NO}_{3}+0.4 * \mathrm{MEO}_{2}$ & - & $1.0 /<$ PAN_IUPAC10 $>$ & \\
\hline $\begin{array}{c}\mathrm{PAN}=0.6^{*} \mathrm{MECO}_{3}+0.6 * \mathrm{NO}_{2}+0.4 * \mathrm{MEO}_{2} \\
+0.4^{\star} \mathrm{CO}_{2}+0.4^{*} \mathrm{NO}_{3}\end{array}$ & - & - & $1.0 /<$ PAN $>$ \\
\hline $\mathrm{PAN}+\mathrm{HO}=\mathrm{XO}_{2}+\mathrm{NO}_{3}+\mathrm{HCHO}$ & $4.0 \mathrm{E}-14$ & - & - \\
\hline
\end{tabular}



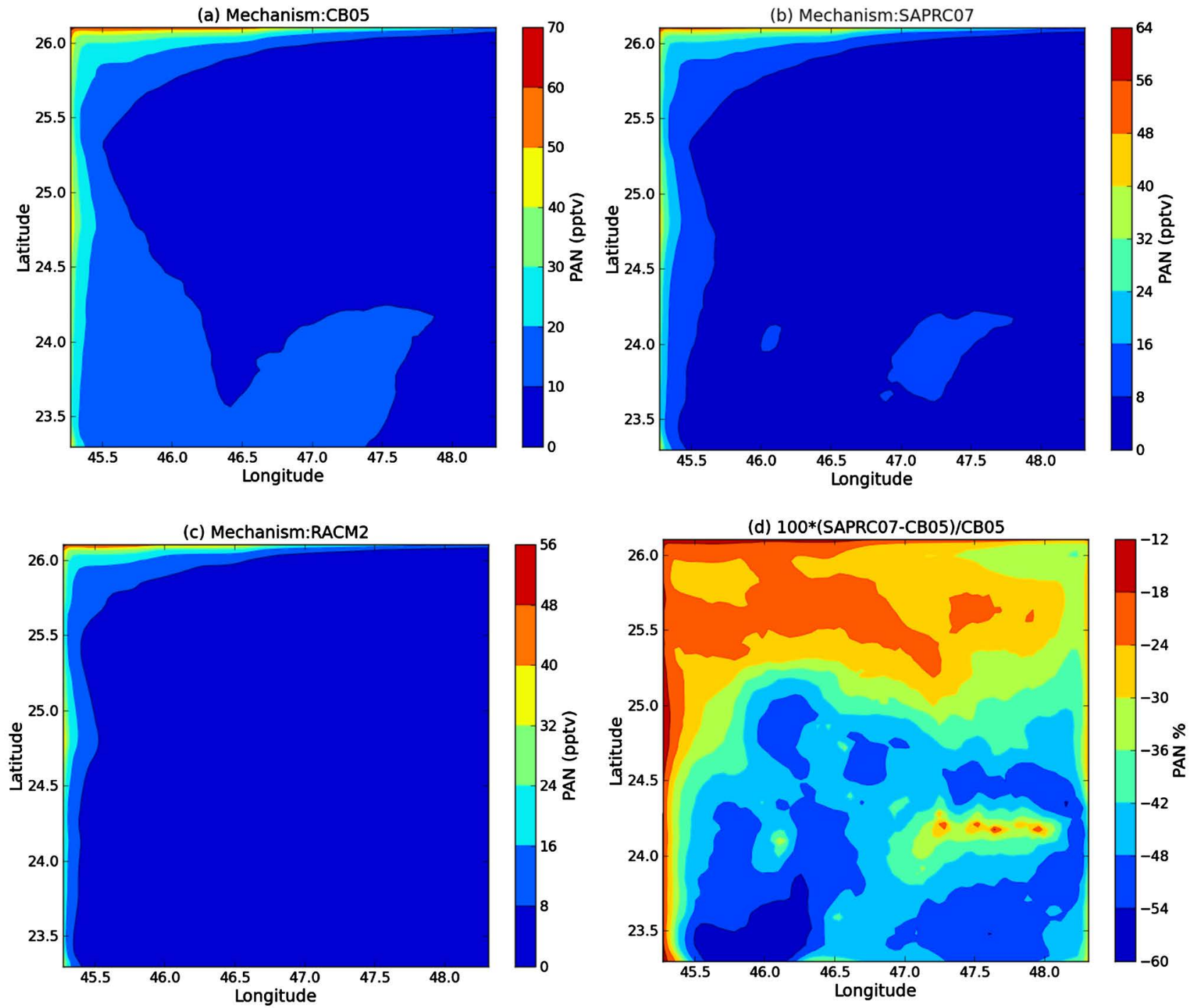

(e) $100 *$ (RACM2-CB05)/CB05
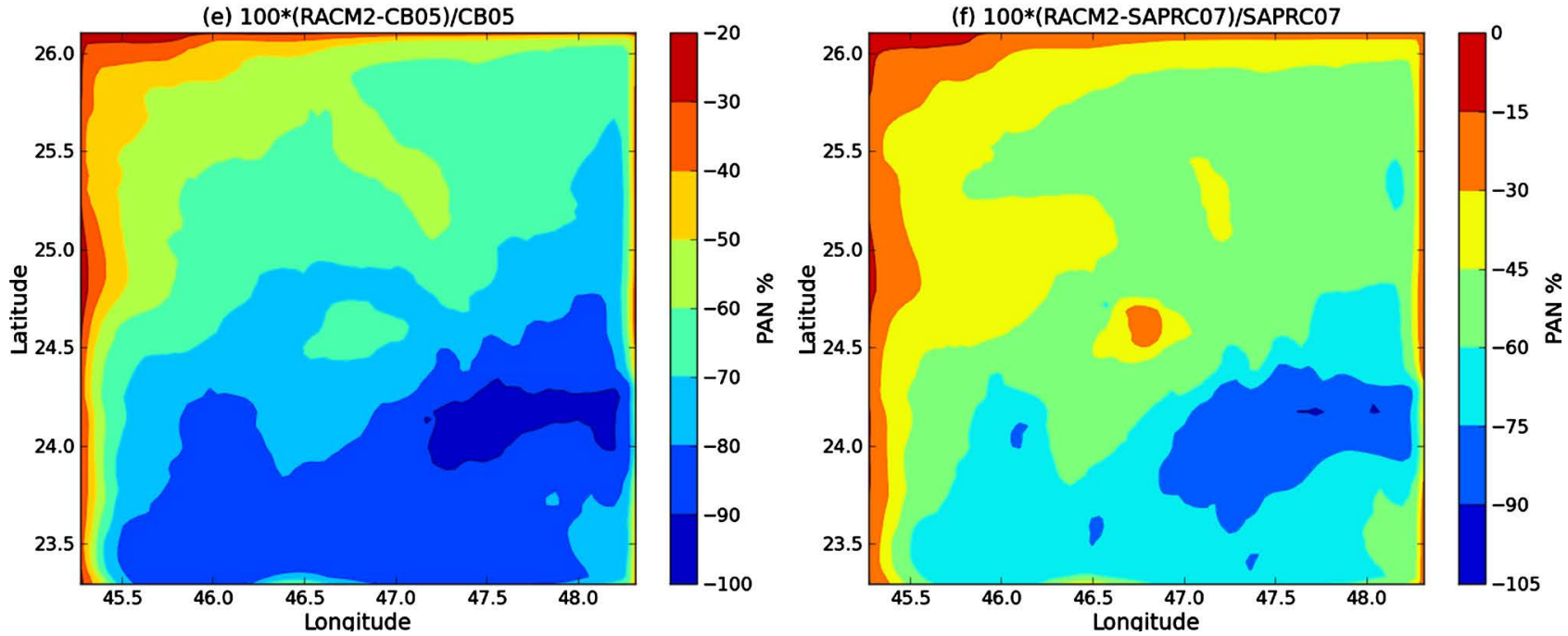

Figure 5. Spatial distribution of predicted mean PAN concentrations obtained with chemical mechanisms (a) CB05 (b) SAPRC07 (c) RACM2 and percent differences between the mechanisms (d) SAPRC07 and CB05 (e) RACM2 and CB05 (f) RACM2 and SAPRC07. 
Table 9. Components in secondary nitrogen species $\left(\mathrm{NO}_{\mathrm{z}}\right)$ in various mechanisms.

\begin{tabular}{|c|c|}
\hline Chemical Mechanism & $\mathrm{NO}_{\mathrm{z}}$ \\
\hline CB05 & $\begin{array}{l}\mathrm{NO}_{3}+2 * \mathrm{~N}_{2} \mathrm{O}_{5}+\mathrm{HONO}+\mathrm{HNO}_{3}+\mathrm{PAN}+\mathrm{PANX}+\mathrm{PNA}+\mathrm{NTRI}+\mathrm{NTRIO} 2+\mathrm{NTRM}+\mathrm{NTRMO}_{2}+\mathrm{NTROH}+\mathrm{NTRPX} \\
+\mathrm{CRON}+\mathrm{CRNO}+\mathrm{CRN} 2+\mathrm{CRPX}+\mathrm{OPAN}\end{array}$ \\
\hline RACM2 & $\mathrm{NO}_{3}+2 * \mathrm{~N}_{2} \mathrm{O}_{5}+\mathrm{HONO}+\mathrm{HNO}_{3}+\mathrm{PAN}+\mathrm{PPN}+\mathrm{MPAN}+\mathrm{HNO}_{4}+\mathrm{ISON}+\mathrm{ONIT}+\mathrm{NALD}+\mathrm{ADCN}+\mathrm{OLNN}+\mathrm{OLND}$ \\
\hline SAPRC07 & $\mathrm{NO}+\mathrm{NO}_{2}+\mathrm{NO}_{3}+2 \mathrm{~N}_{2} \mathrm{O}_{5}+\mathrm{HONO}+\mathrm{HNO}_{3}+\mathrm{HNO}_{4}+\mathrm{PAN}+\mathrm{PAN} 2+\mathrm{PBZN}+\mathrm{MAPAN}+\mathrm{NPHE}$ \\
\hline
\end{tabular}
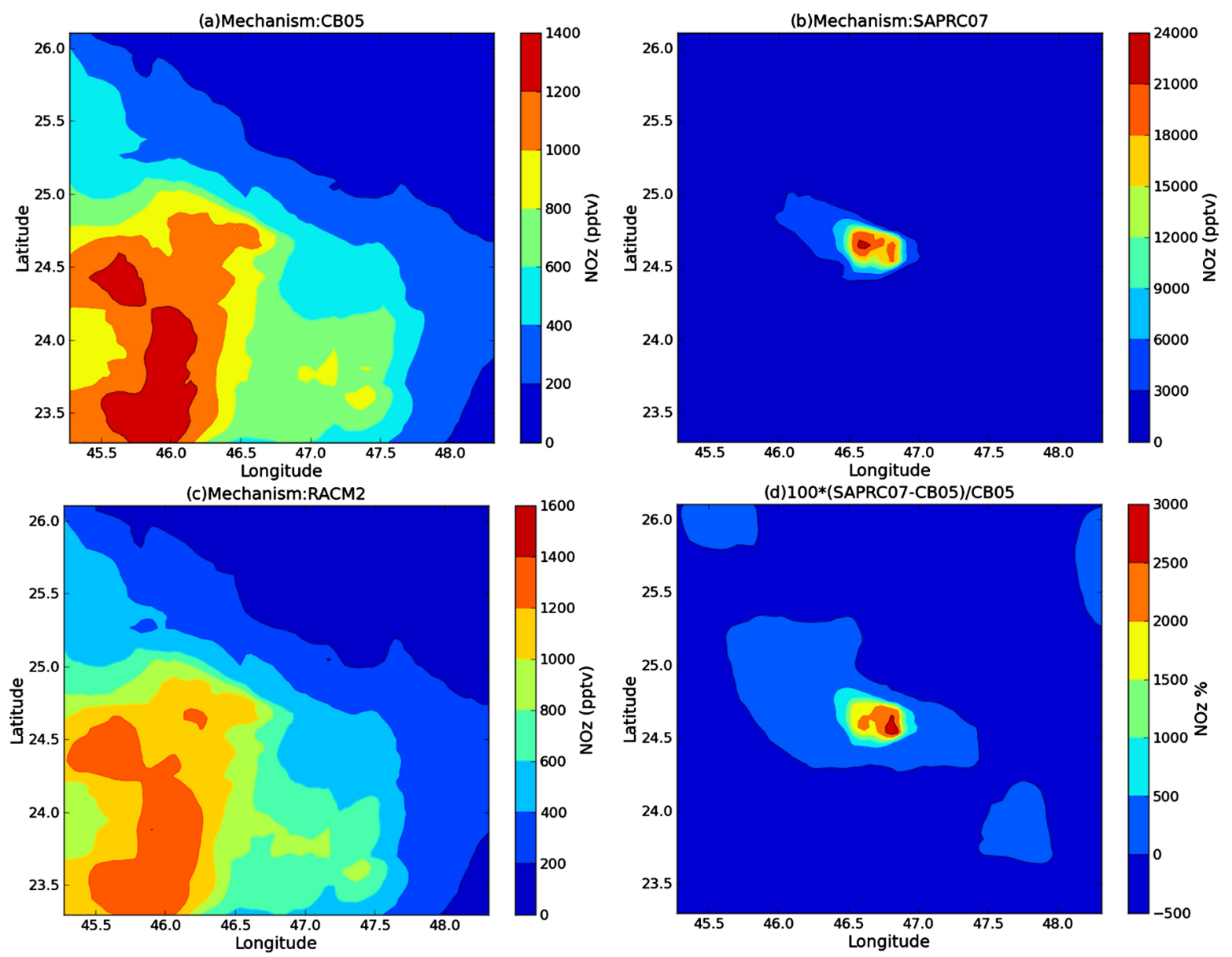

(d) 100*(SAPRC07-CB05)/CB05
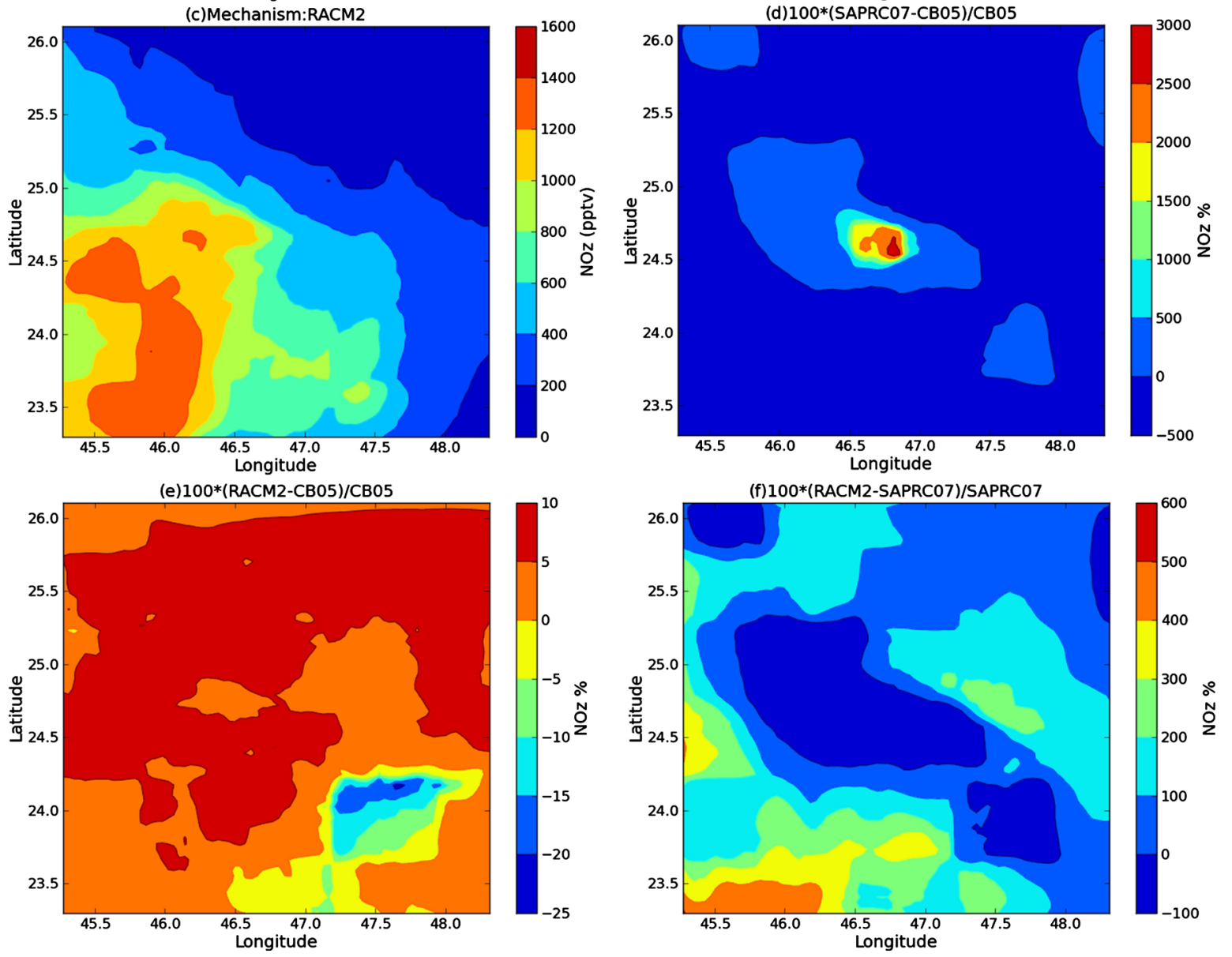

Figure 6. Spatial distribution of predicted mean $\mathrm{NO}_{z}$ concentrations obtained with chemical mechanisms (a) CB05 (b) SAPRC07 (c) RACM2 and percent differences between the mechanisms (d) SAPRC07 and CB05 (e) RACM2 and CB05 (f) RACM2 and SAPRC07. 
predicted by the mechanisms along with percent differences. RACM2 predicts the highest concentration followed by SAPRC07 and CB05. For all the three mechanisms, the lowest concentration was in the southeast area of the domain and the highest was towards the northwest. RACM2 produced about $60 \%$ and $35 \%$ more $\mathrm{NO}_{z}$ than $\mathrm{CB} 05$ and SAPRC07 respectively. The major components of $\mathrm{NO}_{z}$ are organic nitrate (NTR) and PAN which were about 78\% in CB05, 81\% in SAPRC07, and $86 \%$ in RACM2.

3) Formation of $\mathrm{O}_{3}$

4) Effect on Surface $\mathrm{O}_{3}$

As shown in Figure 2 and Table 6, SAPRC07 produced the highest $\mathrm{O}_{3}$ concentration, followed by RACM2 and CB05. SAPRC07 produced approximately $3 \%$ more $\mathrm{O}_{3}$ than RACM2 and approximately $10 \%$ more than CB05. RACM2 predictions were in excess by $7 \%$ over CB05. Comparing RACM2 and CB05 mechanisms in the US domain, Sarwar et al. in 2013 [28] found RACM2 predicted $10 \%$ more $\mathrm{O}_{3}$ than $\mathrm{CB} 05$. Kim et al. in 2009 [47] also compared $\mathrm{O}_{3}$ and observed that RACM2 predicts higher concentration than CB05 in California. The reasons for high production of $\mathrm{O}_{3}$ could be summarized as follows:

- The production and destruction of $\mathrm{O}_{3}$ are primarily governed by reactions of $\mathrm{NO}$ and $\mathrm{NO}_{2}$ with other molecules including $\mathrm{O}_{3}$ such as the reaction $\mathrm{O}_{3}+$ NO. This reaction has a lower reaction rate in RACM2 when compared to CB05 and SAPRC07, and this lower reaction rate keeps the concentration of $\mathrm{O}_{3}$ high.

- $\mathrm{NO}_{2}$ is the primary source for producing $\mathrm{O}$, if it reacts with another molecule such as $\mathrm{OH}$, the $\mathrm{O}_{3}$ concentrations will be lower. In RACM2 the reaction rate of $\mathrm{NO}_{2}+\mathrm{OH}$ is lower, thus more $\mathrm{NO}_{2}$ is available for photolysis, subsequently producing more $\mathrm{O}_{3}$.

- $\mathrm{NO}_{2}$ can also be produced through organic compounds (RO2) by the conversion of NO; these conversions are higher in RACM2, especially by aromatic compounds.

- The organic nitrates recycling reactions are higher in RACM2.

Similar reasons were outlined by Kim et al. in 2009 [47], Shearer et al. in 2012 [48], and Sarwar et al in 2013 [28] for higher $\mathrm{O}_{3}$ production by RACM2 over CB05. In the current scenario as well, RACM2 produced higher than CB05, however, the percent differences are larger. In addition to faster photolysis due to high temperature, the reaction $\mathrm{NO}_{2}+\mathrm{OH}$ is further slowed down, likely due to the shortage of $\mathrm{OH}$ radical in the atmosphere, as the region is arid. Kim et al. in 2009 [47] studied the effect of condensing the updated SAPRC07 mechanism and found that it produced greater $\mathrm{O}_{3}$ concentration, the reasons for which were not evaluated. In the current study, SAPRC07 produced the highest concentration over RACM2 and CB05. Explanations 1 and 2 mentioned above for high $\mathrm{O}_{3}$ concentration cannot be the reasons as reaction rates for SAPRC07 is equal to CB05 rates. In fact, SAPRC07 should produce similar $\mathrm{O}_{3}$ 
concentration to CB05; however, it produces less $\mathrm{O}_{3}$ even than RACM2. However, the role of organic compounds and $\mathrm{NO}_{\mathrm{x}}$ recycling from organic nitrates seems to be predominant in SAPRC07, thus producing more $\mathrm{NO}_{2}$ (e.g. from $\mathrm{HNO}_{4}$ ) which in turn is the reason for the formation of $\mathrm{O}_{3}$. Further analysis on this aspect is required to gain insights by performing sensitivity analysis on these reactions.

Over the course of one month, $\mathrm{O}_{3}$ data were collected at three stations in the domain. The mean $\mathrm{O}_{3}$ concentration at all the three locations was 39.16 ppbv. This observed value is about $6 \%, 11 \%$, and $15 \%$ more than the predicted values by CB05, RACM2 and SAPRC07 respectively.

Spatial variations of the mean $\mathrm{O}_{3}$ predicted by all the three mechanisms are shown in Figure 7. The peak concentrations were generally in the middle and towards the west of the domain. This is likely due to the predominant wind direction that was from the southwest which drives the $\mathrm{O}_{3}$ concentration from north of the domain towards the south. All the three mechanisms share similar spatial distribution pattern, with SAPRC07 having the larger patches of peak concentrations. Figure 7 also illustrates the spatial differences between the mechanisms and differences were observed high towards south of the domain.

\section{5) Diurnal Variation of $\mathrm{O}_{3}$}

Figure 8(a) shows boxplots of hourly diurnal $\mathrm{O}_{3}$ predictions obtained with the six chemical mechanisms. The $\mathrm{O}_{3}$ predicted with all the mechanisms takes a general pattern over the day increasing after sunrise, reaching to maximum at noontime, and subsiding towards the evening. From midnight to 4 am (sunrise), there was no effect of the chemical mechanisms as $\mathrm{O}_{3}$ concentrations were the same. Immediately after sunrise $\mathrm{CB} 05$ started producing more $\mathrm{O}_{3}$ than the others did, and as the day progressed all variations of SAPRC07 (SAPRC07TB, SAPRC07TC, and SAPRC07TIC) produced higher concentrations over the other two i.e., RACM2 and CB05. The concentration differences between various mechanisms were highest during noon time and close to zero during midnight, indicating that the reactions rates in the formation of $\mathrm{O}_{3}$ are sensitive to temperatures. The reactions in SAPRC07 and RACM2 under high temperature produced more $\mathrm{O}_{3}$, while CB05 had no significant change due to high temperatures. The organic aromatic reactions (converting $\mathrm{NO}$ to $\mathrm{NO}_{2}$ ) appeared to take precedence in SAPRC07 and RACM2 under high temperatures. Figure 8(b) illustrates the diurnal variation including the observed data. Generally, the observed data is scattered more than the model values. There is a significant difference in the observed and model-predicted values and this difference is anticipated as the model simulations were performed with biogenic emissions inventory only. During nighttime, the observed values are lower or similar to model values, and there is a significant drop in the concentration in the early morning. Early morning $\mathrm{O}_{3}$ loss is a well-known phenomenon that is also true in Riyadh. There is a huge increase in $\mathrm{O}_{3}$ concentration during the day (from 8 to 17 hours). This 

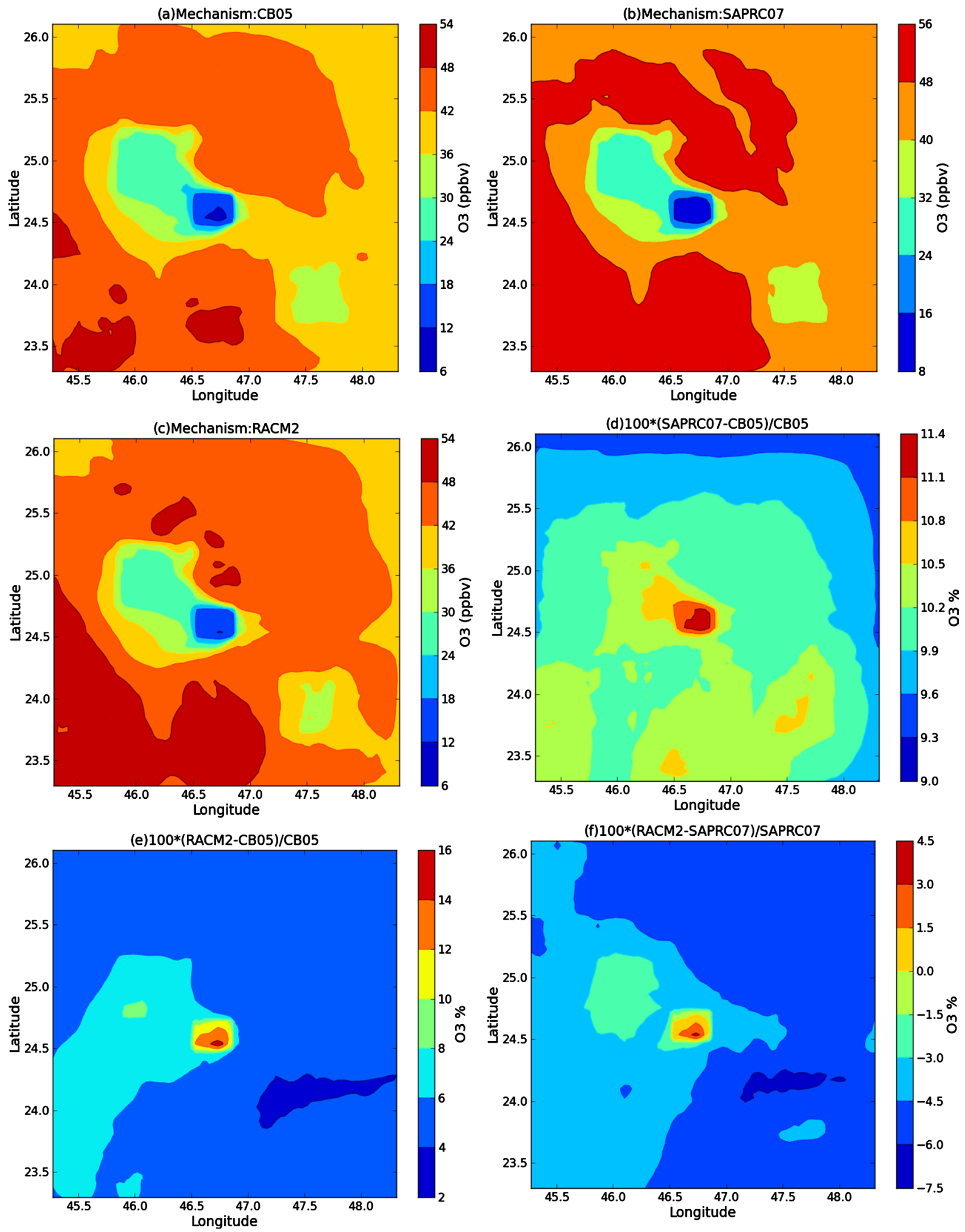

Figure 7. Spatial distribution of predicted mean $\mathrm{O}_{3}$ concentrations obtained with chemical (a) CB05 (b) SAPRC07 (c) RACM2 and percent differences between the mechanisms (d) SAPRC07 and CB05 (e) RACM2 and CB05 (f) RACM2 and SAPRC07. 

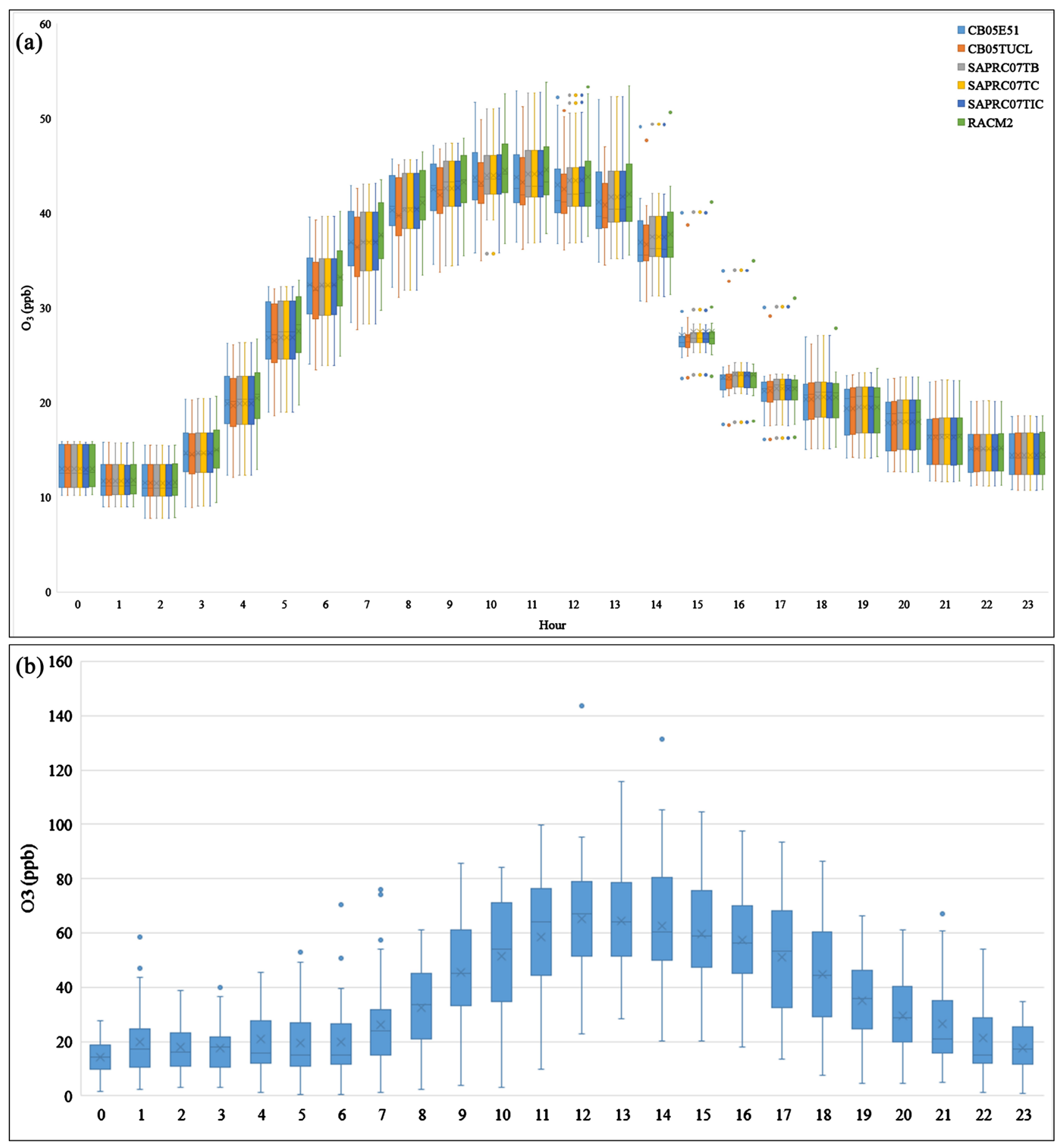

Figure 8. (a) A comparison of diurnal variation of predicted hourly surface $\mathrm{O}_{3}$ obtained with six chemical mechanisms. (b) A comparison of diurnal variation of predicted hourly surface $\mathrm{O}_{3}$ obtained with six chemical mechanisms and observed data.

increase is clearly due to daytime activities most likely the automobile traffic. Evening and late-night values are similar to the model predictions. Some of the things that can be inferred from here are: firstly, the biogenic emissions produce substantial $\mathrm{O}_{3}$ concentrations. In this case, up to $40 \mathrm{ppbv}$, secondly, the spike of observed values during daytime (up to 65\%) indicates significant anthropogenic contributions. 


\section{6) Vertical Distribution of $\mathrm{O}_{3}$}

Figure 9 presents the vertical profiles of $\mathrm{O}_{3}$ predicted by SAPRC07, RACM2 and CB05. These are averaged over the entire domain and modeling period. As depicted in the figure, SAPRC07 continued to enhance $\mathrm{O}_{3}$ over RACM2 and CB05 to approximately $12,000 \mathrm{~m}$, and above that, the three mechanisms produced almost the same $\mathrm{O}_{3}$ concentrations. SAPRC07 enhancement over RACM2 is approximately 1 - 2 ppbv and over CB05 is $4-5$ ppbv. Thus, vertically, SAPRC07 also produces higher $\mathrm{O}_{3}$ concentrations than other mechanisms.

\section{7) Ozone Production Efficiency (OPE)}

The conditions under which $\mathrm{O}_{3}$ forms can be determined by calculating OPE. OPE is defined as the number of molecules of oxidant $\left(\mathrm{O}_{3}+\mathrm{NO}_{2}\right)$ produced photo-chemically when molecules of $\mathrm{NO}_{\mathrm{x}}$ are oxidized [49]. It is generally calculated from the slope of linear regression relationship between daytime $\mathrm{O}_{3}$ and $\mathrm{NO}_{z}$ concentration for aged air masses $\left(\mathrm{O}_{3} / \mathrm{NO}_{\mathrm{x}}>46\right)$ [50]. Figure 10 shows the average OPE calculated over the entire domain and modeling period. The OPE values for CB05, SAPRC07, and RACM2 were 36.5, 19.7, and 13.2 respectively. The observation data was not sufficient to calculate OPE. When compared with other studies OPE values were high. It can potentially be due to the arid weather conditions of the study area. It is also noticed that $\mathrm{CB} 05$ produced more $\mathrm{O}_{3}$ as $\mathrm{NO}_{z}$ increased and this indicates that CB05 mechanisms are more sensitive to $\mathrm{NO}_{\mathrm{z}}$ values in the formation of $\mathrm{O}_{3}$ than RACM2 and SAPRC07. However, the $\mathrm{NO}_{z}$ produced is lesser in CB05 compared to SAPRC07 and RACM2, thus it produces lower $\mathrm{O}_{3}$ concentrations.

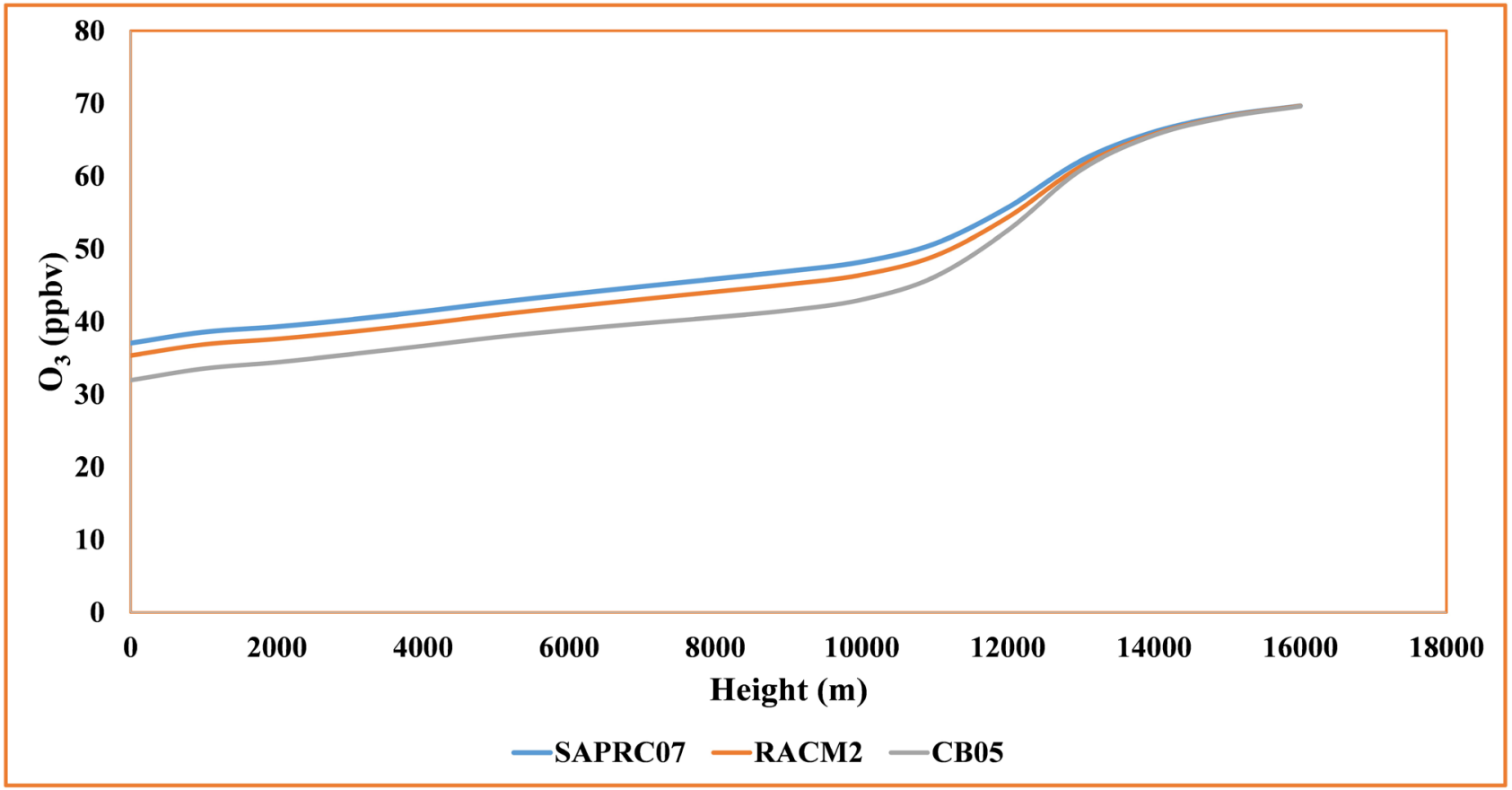

Figure 9. Domain wide mean predicted vertical $\mathrm{O}_{3}$ profile obtained with SAPRC07, RACM2 and CB05 chemical mechanisms during the modeling period. 


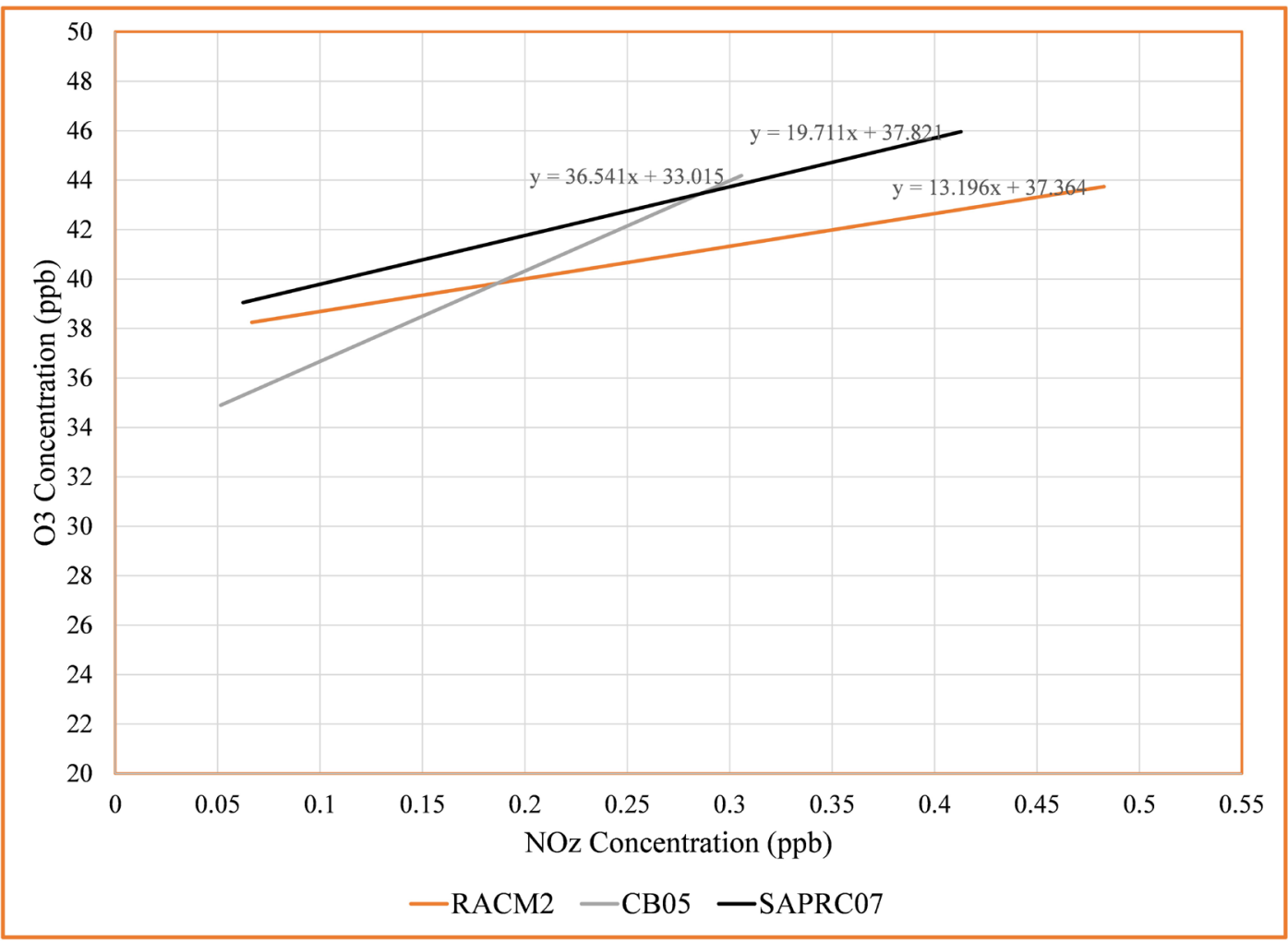

Figure 10. Domain wide mean Ozone production efficiency for three chemical mechanisms

\section{Summary and Conclusions}

This paper investigated the effect of various chemical mechanisms in CMAQ when implemented in the arid region of Saudi Arabia. One month simulations were performed for six different chemical mechanisms and the predicted values were compared for oxidants $\left(\mathrm{OH}\right.$ and $\mathrm{H}_{2} \mathrm{O}_{2}$ ), nitrogen species ( $\mathrm{PAN}$ and $\mathrm{NO}_{\mathrm{z}}$ ), and $\mathrm{O}_{3}$ (diurnal variation, surface distribution and vertical variation). The mechanism CB05TUC produced more oxidants and nitrogen species than CB05E51; however, both mechanisms predicted the same $\mathrm{O}_{3}$ concentrations. There was no significant difference in the production of all parameters among SAPRC07TB, SAPRC07TC, and SAPRC07TIC. RACM2 produced higher $\mathrm{OH}$ concentrations than the other mechanisms, but the enhancements were much less than other studies. This indicates the shortage of the $\mathrm{OH}$ radical in the area is potentially due to the arid conditions. Higher concentrations of the $\mathrm{H}_{2} \mathrm{O}_{2}$ radicals were produced by RACM2, due to the reaction of $\mathrm{O}_{3}$ with alkenes, implying the predominant role of organic compounds in the atmosphere. High PAN concentrations were noticed in the domain by all mechanisms, indicating photochemical smog conditions in certain locations. SAPRC07 produced the highest concentration of surface $\mathrm{O}_{3}$ followed by RACM2 and CB05. A similar pattern was noticed in the vertical variation of $\mathrm{O}_{3}$. When compared with the observed $\mathrm{O}_{3}, \mathrm{CB} 05$ predictions were the closest. Diurnal variation indicated significant spike in $\mathrm{O}_{3}$ during daytime verifying that automobile activities contribute significantly to $\mathrm{O}_{3}$ formation. OPE values were very high compared to other studies. Based on the 
current comparisons, CB05 appears to be the appropriate chemical mechanism to run photochemical models for $\mathrm{O}_{3}$ predictions in dry and arid areas such as the current study. High OPE and PAN concentrations in the domain require further investigation.

\section{Acknowledgements}

We gratefully acknowledge the financial support of King Abdulaziz City for Science and Technology (KACST) under grant number 32-594.

\section{Conflicts of Interest}

The authors declare no conflicts of interest regarding the publication of this paper.

\section{References}

[1] Gery, M.W., Whitten, G.Z., Killus, J.P. and Dodge, M.C. (1989) A Photochemical Kinetics Mechanism for Urban and Regional Scale Computer Modeling. Journal of Geophysical Research: Atmospheres, 94, 12925-12956. https://doi.org/10.1029/JD094iD10p12925

[2] Stockwell, W.R. (1986) A Homogeneous Gas Phase Mechanism for Use in a Regional Acid Deposition Model. Atmospheric Environment, 20, 1615-1632. https://doi.org/10.1016/0004-6981(86)90251-9

[3] Carter, W.P. (2000) Implementation of the SAPRC-99 Chemical Mechanism into the Models-3 Framework. Report to the United States Environmental Protection Agency, Washington DC.

[4] Carter, W.P. and Atkinson, R. (1996) Development and Evaluation of a Detailed Mechanism for the Atmospheric Reactions of Isoprene and NOx. International Journal of Chemical Kinetics, 28, 497-530. https://doi.org/10.1002/(SICI)1097-4601(1996)28:7<497::AID-KIN4>3.0.CO;2-Q

[5] Yarwood, G., Rao, S., Yocke, M. and Whitten, G. (2005) Updates to the Carbon Bond Chemical Mechanism: CB05. Final Report to the US EPA, RT-0400675. http://www.camx.com http://www.camx.com/files/cb05_final_report_120805.aspx

[6] Sarwar, G., Luecken, D., Yarwood, G., Whitten, G.Z. and Carter, W.P. (2008) Impact of an Updated Carbon Bond Mechanism on Predictions from the CMAQ Modeling System: Preliminary Assessment. Journal of Applied Meteorology and Climatology, 47, 3-14. https://doi.org/10.1175/2007JAMC1393.1

[7] Whitten, G.Z., Heo, G., Kimura, Y., McDonald-Buller, E., Allen, D.T., Carter, W.P. and Yarwood, G. (2010) A New Condensed Toluene Mechanism for Carbon Bond: CB05-TU. Atmospheric Environment, 44, 5346-5355.

https://doi.org/10.1016/j.atmosenv.2009.12.029

[8] Digar, A., Cohan, D.S., Cox, D.D., Kim, B.U. and Boylan, J.W. (2010) Likelihood of Achieving Air Quality Targets under Model Uncertainties. Environmental Science \& Technology, 45, 189-196. https://doi.org/10.1021/es102581e

[9] Foley, K.M., Napelenok, S.L., Jang, C., Phillips, S., Hubbell, B.J. and Fulcher, C.M. (2014) Two Reduced form Air Quality Modeling Techniques for Rapidly Calculating Pollutant Mitigation Potential across Many Sources, Locations and Precursor Emission Types. Atmospheric Environment, 98, 283-289. 
https://doi.org/10.1016/j.atmosenv.2014.08.046

[10] Foley, K.M., Hogrefe, C., Pouliot, G., Possiel, N., Roselle, S.J., Simon, H. and Timin, B. (2015) Dynamic Evaluation of CMAQ Part I: Separating the Effects of Changing Emissions and Changing Meteorology on Ozone Levels between 2002 and 2005 in the Eastern US. Atmospheric Environment, 103, 247-255.

https://doi.org/10.1016/j.atmosenv.2014.12.038

[11] Appel, K.W., Roselle, S.J., Gilliam, R.C. and Pleim, J.E. (2010) Sensitivity of the Community Multiscale Air Quality (CMAQ) Model v4.7 Results for the Eastern United States to MM5 and WRF Meteorological Drivers. Geoscientific Model Development, 3, 169-188. https://doi.org/10.5194/gmd-3-169-2010

[12] Li, L., Chen, C., Huang, C., Huang, H., Zhang, G., Wang, Y., Chen, M., Wang, H., Chen, Y., Streets, D.G. and Fu, J. (2011) Ozone Sensitivity Analysis with the MM5-CMAQ Modeling System for Shanghai. Journal of Environmental Sciences, 23, 1150-1157. https://doi.org/10.1016/S1001-0742(10)60527-X

[13] Gupta, M. and Mohan, M. (2015) Validation of WRF/Chem Model and Sensitivity of Chemical Mechanisms to Ozone Simulation over Megacity Delhi. Atmospheric Environment, 122, 220-229. https://doi.org/10.1016/j.atmosenv.2015.09.039

[14] Dunker, A.M., Yarwood, G., Ortmann, J.P. and Wilson, G.M. (2002) The Decoupled Direct Method for Sensitivity Analysis in a Three-Dimensional Air Quality Model Implementation, Accuracy, and Efficiency. Environmental Science \& Technology, 36, 2965-2976. https://doi.org/10.1021/es0112691

[15] IUPAC (2010) IUPAC Subcommittee for Gas Kinetic Data Evaluation. http://www.iupac-kinetic.ch.cam.ac.uk

[16] Stockwell, W.R., Middleton, P., Chang, J.S. and Tang, X. (1990) The Second Generation Regional Acid Deposition Model Chemical Mechanism for Regional Air Quality Modeling. Journal of Geophysical Research: Atmospheres, 95, 16343-16367. https://doi.org/10.1029/JD095iD10p16343

[17] Zimmermann, J. and Poppe, D. (1996) A Supplement for the RADM2 Chemical Mechanism: The Photooxidation of Isoprene. Atmospheric Environment, 30, 1255-1269. https://doi.org/10.1016/1352-2310(95)00417-3

[18] Goliff, W.S., Stockwell, W.R. and Lawson, C.V. (2013) The Regional Atmospheric Chemistry Mechanism, Version 2. Atmospheric Environment, 68, 174-185. https://doi.org/10.1016/j.atmosenv.2012.11.038

[19] Sander, S.P., Abbatt, J.P.D., Barker, J.R., Burkholder, J.B., Friedl, R.R., Golden, D.M., Huie, R.E., Kolb, C.E., Kurylo, M.J., Moortgat, G.K., Orkin, V.L. and Wine, P.H. (2011) Chemical Kinetics and Photochemical Data for Use in Atmospheric Studies, Evaluation No. 17. Jet Propulsion Laboratory, Pasadena.

[20] Zheng, B., Zhang, Q., Zhang, Y., He, K.B., Wang, K., Zheng, G.J., Duan, F.K., Ma, Y.L. and Kimoto, T. (2015) Heterogeneous Chemistry: A Mechanism Missing in Current Models to Explain Secondary Inorganic Aerosol Formation during the January 2013 Haze Episode in North China. Atmospheric Chemistry and Physics, 15, 2031-2049. https://doi.org/10.5194/acp-15-2031-2015

[21] Baró, R., Jiménez-Guerrero, P., Balzarini, A., Curci, G., Forkel, R., Grell, G., Hirtl, M., Honzak, L., Langer, M., Pérez, J.L. and Pirovano, G. (2015) Sensitivity Analysis of the Microphysics Scheme in WRF-Chem Contributions to AQMEII Phase 2. Atmospheric Environment, 115, 620-629. https://doi.org/10.1016/j.atmosenv.2015.01.047

[22] Jimenez, P., Baldasano, J.M. and Dabdub, D. (2003) Comparison of Photochemical Mechanisms for Air Quality Modeling. Atmospheric Environment, 37, 4179-4194. 
https://doi.org/10.1016/S1352-2310(03)00567-3

[23] Gross, A. and Stockwell, W.R. (2003) Comparison of the EMEP, RADM2 and RACM Mechanisms. Journal of Atmospheric Chemistry, 44, 151-170. https://doi.org/10.1023/A:1022483412112

[24] Tonnesen, G.S. and Luecken, D. (2004) Intercomparison of Photochemical Mechanisms Using Response Surfaces and Process Analysis. In: Air Pollution Modeling and Its Application XIV, Springer, Berlin, 511-519. https://doi.org/10.1007/0-306-47460-3_52

[25] Byun, D. and Schere, K.L. (2006) Review of the Governing Equations, Computational Algorithms, and Other Components of the Models-3 Community Multiscale Air Quality (CMAQ) Modeling System. Applied Mechanics Reviews, 59, 51-77. https://doi.org/10.1115/1.2128636

[26] Faraji, M., Kimura, Y., McDonald-Buller, E. and Allen, D. (2008) Comparison of the Carbon Bond and SAPRC Photochemical Mechanisms under Conditions Relevant to Southeast Texas. Atmospheric Environment, 42, 5821-5836. https://doi.org/10.1016/j.atmosenv.2007.07.048

[27] Luecken, D.J., Phillips, S., Sarwar, G. and Jang, C. (2008) Effects of Using the CB05 vs. SAPRC99 vs. CB4 Chemical Mechanism on Model Predictions: Ozone and Gas-Phase Photochemical Precursor Concentrations. Atmospheric Environment, 42, 5805-5820. https://doi.org/10.1016/j.atmosenv.2007.08.056

[28] Sarwar, G., Godowitch, J., Henderson, B.H., Fahey, K., Pouliot, G., Hutzell, W.T., Mathur, R., Kang, D., Goliff, W.S. and Stockwell, W.R. (2013) A Comparison of Atmospheric Composition Using the Carbon Bond and Regional Atmospheric Chemistry Mechanisms. Atmospheric Chemistry and Physics, 13, 9695-9712. https://doi.org/10.5194/acp-13-9695-2013

[29] Meo, S.A., Al-Kheraiji, M.F.A., AlFaraj, Z.F., Alwehaibi, N.A. and Aldereihim, A.A. (2013) Respiratory and General Health Complaints in Subjects Exposed to Sandstorm at Riyadh, Saudi Arabia. Pakistan Journal of Medical Sciences, 29, 642-646. https://doi.org/10.12669/pjms.292.3065

[30] Rushdi, A.I., Al-Mutlaq, K.F., Al-Otaibi, M., El-Mubarak, A.H. and Simoneit, B.R. (2013) Air Quality and Elemental Enrichment Factors of Aerosol Particulate Matter in Riyadh City, Saudi Arabia. Arabian Journal of Geosciences, 6, 585-599. https://doi.org/10.1007/s12517-011-0357-9

[31] Alharbi, B., Shareef, M.M. and Husain, T. (2015) Study of Chemical Characteristics of Particulate Matter Concentrations in Riyadh, Saudi Arabia. Atmospheric Pollution Research, 6, 88-98. https://doi.org/10.5094/APR.2015.011

[32] CMAS (2016) Community Modeling \& Analysis System. https://www.cmascenter.org/cmaq/

[33] Cohan, D.S., Koo, B. and Yarwood, G. (2010) Influence of Uncertain Reaction Rates on Ozone Sensitivity to Emissions. Atmospheric Environment, 44, 3101-3109. https://doi.org/10.1016/j.atmosenv.2010.05.034

[34] Simon, H., Baker, K.R., Akhtar, F., Napelenok, S.L., Possiel, N., Wells, B. and Timin, B. (2013) A Direct Sensitivity Approach to Predict Hourly Ozone Resulting from Compliance with the National Ambient Air Quality Standard. Environmental Science \& Technology, 47, 2304-2313. https://doi.org/10.1021/es303674e

[35] Wang, L., Xu, J., Yang, J., Zhao, X., Wei, W., Cheng, D., Pan, X. and Su, J. (2012) Understanding Haze Pollution over the Southern Hebei Area of China Using the CMAQ Model. Atmospheric Environment, 56, 69-79.

https://doi.org/10.1016/j.atmosenv.2012.04.013 
[36] Huang, K., Fu, J.S., Hsu, N.C., Gao, Y., Dong, X., Tsay, S.C. and Lam, Y.F. (2013) Impact Assessment of Biomass Burning on Air Quality in Southeast and East Asia during BASE-ASIA. Atmospheric Environment, 78, 291-302. https://doi.org/10.1016/j.atmosenv.2012.03.048

[37] Arunachalam, S., Wang, B., Davis, N., Baek, B.H. and Levy, J.I. (2011) Effect of Chemistry-Transport Model Scale and Resolution on Population Exposure to PM 2.5 from Aircraft Emissions during Landing and Takeoff. Atmospheric Environment, 45, 3294-3300. https://doi.org/10.1016/j.atmosenv.2011.03.029

[38] Skamarock, W.C., Klemp, J.B., Dudhia, J., Grill, D.O., Barker, D.M., Duda, M.G., Huang, X.-Y., Wang, W. and Powers, J.G. (2008) A Description of the Advanced Research WRF Version 3. NCAR Tech Note NCAR/TN 475 STR, Boulder.

[39] Sandu, A., Verwer, J.G., Blom, J.G., Spee, E.J., Carmichael, G.R. and Potra, F.A. (1997) Benchmarking Stiff ODE Solvers for Atmospheric Chemistry Problems II: Rosenbrock Solvers. Atmospheric Environment, 31, 3459-3472. https://doi.org/10.1016/S1352-2310(97)83212-8

[40] Harley, R.A., Brown, N.J., Tonse, S.R. and Jin, L. (2006) A Seasonal Perspective on Regional Air Quality in Central California: Phase I Final Report for San Joaquin Valley Wide Air Pollution Study Agency and the California Air Resources Board, Report. Department of Civil and Environmental Engineering, University of California, Berkeley. https://doi.org/10.2172/913278

[41] Guenther, A.B., Jiang, X., Heald, C.L., Sakulyanontvittaya, T., Duhl, T., Emmons, L.K. and Wang, X. (2012) The Model of Emissions of Gases and Aerosols from Nature Version 2.1 (MEGAN2. 1): An Extended and Updated Framework for Modeling Biogenic Emissions. Geosciences Model Development, 5, 1471-1492. https://doi.org/10.5194/gmd-5-1471-2012

[42] MEGAN (2014) Model of Emissions of Gases and Aerosols from Nature (MEGAN). https://bai.ess.uci.edu/megan/versions

[43] ESRI Environment Science Research Institute (2016). http://www.esri.com

[44] Carter, W.P.L. (2015) Development of an Improved Chemical Speciation Database for Processing Emissions of Volatile Organic Compounds for Air Quality Models. http://www.engr.ucr.edu/ carter/emitdb

[45] Lu, K.D., et al. (2013) Missing OH Source in a Suburban Environment near Beijing: Observed and Modelled $\mathrm{OH}$ and $\mathrm{HO} 2$ Concentrations in Summer 2006. Atmospheric Chemistry and Physics, 13, 1057-1080. https://doi.org/10.5194/acp-13-1057-2013

[46] Seinfeld, J.H. and Pandis, S.N. (2012) Atmospheric Chemistry and Physics: From Air Pollution to Climate Change. John Wiley \& Sons, Hoboken.

[47] Kim, Y., Sartelet, K. and Seigneur, C. (2009) Comparison of Two Gas-Phase Chemical Kinetic Mechanisms of Ozone Formation over Europe. Journal of Atmospheric Chemistry, 62, 89-119. https://doi.org/10.1007/s10874-009-9142-5

[48] Shearer, S.M., Harley, R.A., Jin, L. and Brown, N.J. (2012) Comparison of SAPRC99 and SAPRC07 Mechanisms in Photochemical Modeling for Central California. Atmospheric Environment, 46, 205-216. https://doi.org/10.1016/j.atmosenv.2011.09.079

[49] Kleinman, L.I., Daum, P.H., Lee, Y.N., Nunnermacker, L.J., Springston, S.R., Weinstein-Lloyd, J. and Rudolph, J. (2002) Ozone Production Efficiency in an Urban Area. Journal of Geophysical Research: Atmospheres, 107, ACH 23-1-ACH 23-12. https://doi.org/10.1029/2002JD002529

[50] Arnold, J.R. and Dennis, R.L. (2006) Testing CMAQ Chemistry Sensitivities in Base 
Case and Emissions Control Runs at SEARCH and SOS99 Surface Sites in the Southeastern US. Atmospheric Environment, 40, 5027-5040.

https://doi.org/10.1016/j.atmosenv.2005.05.055

[51] WRF (2016). http://www.mmm.ucar.edu/wrf/users/downloads.html

[52] Iacono, M.J., Delamere, J.S., Mlawer, E.J., Shephard, M.W., Clough, S.A. and Collins, W.D. (2008) Radiative Forcing by Long-Lived Greenhouse Gases: Calculations with the AER Radiative Transfer Models. Journal of Geophysical Research: Atmospheres, 113. https://doi.org/10.1029/2008JD009944

[53] Chen, F. and Dudhia, J. (2001) Coupling an Advanced Land Surface-Hydrology Model with the Penn State-NCAR MM5 Modeling System. Part I: Model Implementation and Sensitivity. Monthly Weather Review, 129, 569-585.

https://doi.org/10.1175/1520-0493(2001)129<0569:CAALSH>2.0.CO;2

[54] Janjic, Z.I. (1994) The Step-Mountain Eta Coordinate Model: Further Developments of the Convection, Viscous Sublayer, and Turbulence Closure Schemes. Monthly Weather Review, 122, 927-945. https://doi.org/10.1175/1520-0493(1994)122<0927:TSMECM>2.0.CO;2

[55] Kain, J.S. (2004) The Kain-Fritsch Convective Parameterization: An Update. Journal of Applied Meteorology, 43, 170-181.

https://doi.org/10.1175/1520-0450(2004)043<0170:TKCPAU>2.0.CO;2 